\title{
A Bibliometric Survey of Paraffin/Olefin Separation Using Membranes
}

\author{
Débora Micheline Vaz de Miranda ${ }^{1}$, Luciana da Silva Dutra ${ }^{2}$, Débora Way ${ }^{1}{ }^{(0)}$, \\ Nicolis Amaral ${ }^{1}$, Frederico Wegenast ${ }^{1}$, Maria Clara Scaldaferri ${ }^{3}$, Normando Jesus ${ }^{3}$ and \\ José Carlos Pinto ${ }^{1, *}$ \\ 1 Programa de Engenharia Química/COPPE, Universidade Federal do Rio de Janeiro, Cidade Universitária, \\ CP 68502, Rio de Janeiro 21941-972, Brazil; dmiranda@peq.coppe.ufrj.br (D.M.V.d.M.); \\ dway@peq.coppe.ufrj.br (D.W.); nicolis.amaral@yahoo.com.br (N.A.); fwegenast@peq.coppe.ufrj.br (F.W.) \\ 2 Escola de Química, Universidade Federal do Rio de Janeiro, Cidade Universitária, CP 68525, \\ Rio de Janeiro 21941-598, Brazil; ldutra@eq.ufrj.br \\ 3 Braskem S.A., Rua Marumbi, 1400, Campos Elíseos, Duque de Caxias 25221-000, Brazil; \\ clara.scaldaferri@braskem.com (M.C.S.); normando.jesus@braskem.com (N.J.) \\ * Correspondence: pinto@peq.coppe.ufri.br; Tel.: +55-21-3938-8709
}

Received: 11 October 2019; Accepted: 30 October 2019; Published: 26 November 2019

\begin{abstract}
Bibliometric studies allow to collect, organize and process information that can be used to guide the development of research and innovation and to provide basis for decision-making. Paraffin/olefin separations constitute an important industrial issue because cryogenic separation methods are frequently needed in industrial sites and are very expensive. As a consequence, the use of membrane separation processes has been extensively encouraged and has become an attractive alternative for commercial separation processes, as this may lead to reduction of production costs, equipment size, energy consumption and waste generation. For these reasons, a bibliometric survey of paraffin/olefin membrane separation processes is carried out in the present study in order to evaluate the maturity of the technology for this specific application. Although different studies have proposed the use of distinct alternatives for olefin/paraffin separations, the present work makes clear that consensus has yet to be reached among researchers and technicians regarding the specific membranes and operation conditions that will make these processes scalable for large-scale commercial applications.
\end{abstract}

Keywords: membrane; olefin/paraffin; membrane technology; gas separation; bibliometry

\section{Introduction}

Cost-effective gas separation technologies are required in many important industrial applications to withstand the harsh operating conditions of a petroleum refinery [1]. Particularly, cryogenic distillation is the commonest technology employed for purification of gaseous streams, despite the high costs of cryogenic operations and equipment. For this reason, the use of separation technologies based on adsorption, absorption and membranes has been encouraged lately in order to reduce energy costs and improve gas separation efficiencies. However, some inherent characteristics of these technologies (such as sensitivity to impurities, degradation of separation materials, narrow ranges of operation conditions, among others) still negatively affect their full acceptance and prevent the replacement of the expensive cryogenic distillation techniques [1,2]. For example, absorption columns may be unable to handle very high and low flow rates, demand high capital investments and require high operational costs. Besides, solvent regeneration may lead to significant energy consumption, while unavoidable solvent loss increases the environmental impacts of the process, due to solvent emissions, among 
other causes. On the other hand, adsorption processes may be subject to kinetic limitations and loss of sorption capacity over multiple adsorption cycles. Additionally, adsorbent particles may present thermal, chemical and mechanical stability issues, which can lead to particle erosion and degradation over the operation cycles. In turn, membranes usually suffer from poisoning by impurities present in the feed streams and most membrane processes have not been validated industrially yet [3]. More specifically, facilitated transport membranes usually lack stability due to the loss of the carrier during the operation or inactivation of the carrier in the presence of impurities [4]. As carbon molecular sieves are brittle, these alternative materials require careful handling, and may be much more expensive than polymeric membranes [5]. Similarly, alternative ceramic and zeolite membranes can also be subject to poisoning by minor components present in the feed stream [6]. Finally, most polymeric membranes do not resist severe operating conditions (such as high temperatures) and the presence of many organic vapors and solvents [7], showing low selectivity to olefin/paraffin separation [8].

Despite the previous remarks, the main advantage of using membranes for gas separation is the fact that membrane processes can allow for process intensification, leading to significant reduction of production costs, equipment size, energy consumption and waste generation. Besides, membranes can usually be provided by manufacturers and installed in plant sites in modules, allowing for easier fitting to the particular process demands [5]. Consequently, membrane separation processes have gained industrial acceptance and compete favorably with other consolidated operations in some specific niches of gas separation. In particular, the use of membranes for separation of $\mathrm{N}_{2} / \mathrm{O}_{2}[5]$, $\mathrm{CH}_{4} / \mathrm{CO}_{2}$ [9-46], $\mathrm{N}_{2} / \mathrm{CO}_{2}$ [47-52] and $\mathrm{H}_{2} / \mathrm{CO}_{2}$ [11] streams has become industrially attractive and commercially available. Air Products, Generon, Honeywell UOP and Schlumberger are some of the players that are involved with the production of membranes for gas separation. Therefore, there are many indicatives that membrane technology has vast potential to overcome energy issues encountered in cryogenic distillation processes and that membrane technologies will deserve deeper technical and scientific attention in the near future [53].

Otherwise, one of the main difficulties of most membrane technologies is the simultaneous obtainment of high separation selectivities and high permeabilities (or process productivities) [54], which many times hampers the commercial use of membrane technologies. This undesired effect is related to the fact that there is an upper bound on the trade-off between membrane permeability, which limits flow rates, and the selectivity, which limits the quality of the separation process [54]. According to Robeson $[55,56]$, the inverse relationship between selectivity and permeability can be observed for most pairs of permeable gases and polymeric membranes, which leads to a practical limit named as the Robeson's Upper Bound [56], which can be correlated with the molecular characteristics of the permeating gas and of the polymer used to manufacture the membrane barrier. These correlations can be eventually used for design of membrane materials and improvement of gas separation processes [57].

For this reason, development of effective membrane separations can be rather complex and normally requires a great deal of research and development in order to deliver acceptable commercial performances [58]. As a consequence, it is not surprising to observe that different types of membrane technologies have been proposed throughout the years and that the field continues to evolve [8,59].

Olefins are among the most important products of a petrochemical industry because they are used as intermediates for manufacture of many other chemicals [60]. For this reason, olefin/paraffin separation is one of the most important processes in oil refineries. As a matter of fact, even very small improvements in this area may exert an enormous financial impact on the economical performances of refineries. Additionally, the growing demand for olefins, such as ethylene and propylene, especially in emerging consumer markets, creates new opportunities for technologies that can lead to increase of olefin supply and reduction of production costs $[8,59,61]$. As a consequence, membrane separations can constitute excellent alternatives to expensive distillation processes $[1,2,5]$.

Despite that, membrane-based processes still do not find full industrial acceptance in the field of paraffin/olefin separations, which encourages the conduction of bibliometric analyses to characterize the maturity and the main bottlenecks of this technology. Particularly, Tables 1 and 2 summarize the 
membranes and the respective separation mechanisms that have been presented most often as possible solutions for separation of olefin/paraffin streams, as well as the key challenges that affect the progress in this area.

Table 1. Characteristics of membrane systems used most often to separate olefin/paraffin streams.

\begin{tabular}{|c|c|c|}
\hline Membrane Type & Definition and Characteristics & Drawbacks \\
\hline CMS & $\begin{array}{l}\text { Carbon molecular sieves constitute a class of } \\
\text { amorphous carbon materials produced through the } \\
\text { pyrolysis of microporous polymer } \\
\text { precursors }[8,59,62] \text {. Although the surface area is } \\
\text { relatively small, the characteristic pore sizes are } \\
\text { small with narrow size distributions, enabling the } \\
\text { separation at molecular level based on the size and } \\
\text { shape of the molecules }[8,63] \text {. }\end{array}$ & $\begin{array}{l}\text { The pore diameters can be significantly different } \\
\text { from characteristic sizes of molecules that must } \\
\text { be separated. CMS materials can be fragile and } \\
\text { it may be difficult to scale-up the production } \\
\text { process }[59,64] \text {. }\end{array}$ \\
\hline Polymer & $\begin{array}{c}\text { Polymer membranes can be casted with different } \\
\text { thicknesses and porosities (PIMs) }[2,58] \text {. Carriers } \\
\text { can be easily added to allow for; facilitated } \\
\text { transport }[8,65] \text {. }\end{array}$ & $\begin{array}{l}\text { Polymer films can present low gas permeabilities } \\
\text { and selectivities [8] and are subject to swelling, } \\
\text { plasticization, and heterogeneous structure and } \\
\text { porosity [66]. Carriers can be subject to } \\
\text { deactivation by poisonous agents [59]. }\end{array}$ \\
\hline Zeolite & $\begin{array}{c}\text { Zeolites are hydrated aluminosilicate materials, } \\
\text { which possess outstanding ion-exchange and } \\
\text { sorption properties }[8,67] \text {. Separation is based on } \\
\text { pore sizes and polarity, which can be uniform [66] } \\
\text { and are controllable [8]. Zeolites present higher } \\
\text { thermal and chemical stabilities than polymers, } \\
\text { large surface areas, high selectivities and high } \\
\text { permeabilities }[8,68]\end{array}$ & $\begin{array}{l}\text { Preparation conditions can be aggressive, with } \\
\text { combination of high temperatures, high } \\
\text { pressures and extreme } \mathrm{pH} \text { values. The ranges of } \\
\text { pore sizes can be narrow, adhesion properties } \\
\text { onto different substrates can be poor and the } \\
\text { production costs can be high }[66,69] .\end{array}$ \\
\hline MOF & $\begin{array}{l}\text { Metal organic frameworks are hybrid materials } \\
\text { constituted by metallic nodes, which are linked to } \\
\text { each other through organic bridges, leading to } \\
\text { functional porous structures }[66,70] .\end{array}$ & $\begin{array}{l}\text { The manufacture of continuous MOF layers can } \\
\text { be difficult and the produced films can be very } \\
\text { fragile. Adhesion properties onto different } \\
\text { substrates can be poor and the production costs } \\
\text { can be high [66]. }\end{array}$ \\
\hline MMM & $\begin{array}{l}\text { Mixed matrix membranes are hybrid materials } \\
\text { produced through mixing of polymers and } \\
\text { inorganic fillers, including activated carbon, carbon } \\
\text { nanotubes, zeolites, silica, molecular sieves, and } \\
\text { MOFs [66]. Consequently, the final membrane } \\
\text { properties can be manipulated with high flexibility. }\end{array}$ & $\begin{array}{l}\text { The matrix and fillers must be compatible and } \\
\text { filler aggregation and sedimentation must be } \\
\text { prevented during membrane preparation [8]. }\end{array}$ \\
\hline
\end{tabular}

Table 2. Usual mechanisms of olefin/paraffin separation through membranes.

\begin{tabular}{|c|c|c|c|}
\hline $\begin{array}{c}\text { Separation } \\
\text { Mechanisms }\end{array}$ & Membrane Material & Permeation Mechanisms & Drawbacks \\
\hline Solution-diffusion & Polymers & $\begin{array}{l}\text { (1) Molecules adsorb and dissolve into } \\
\text { the membrane material. (2) Molecules } \\
\text { diffuse through the membrane, driven } \\
\text { by pressure, temperature or } \\
\text { concentration gradients. (3) Molecules } \\
\text { desorb into the bulk stream in the } \\
\text { permeate side [8]. }\end{array}$ & $\begin{array}{l}\text { Gas solubility in conventional } \\
\text { polymer membranes is closely } \\
\text { related to compressibility [8]. } \\
\text { Discrimination of } \\
\text { olefin/paraffin pairs is not } \\
\text { effective [59]. }\end{array}$ \\
\hline $\begin{array}{l}\text { Interaction } \\
\text { between olefin } \\
\text { and membrane }\end{array}$ & $\begin{array}{l}\text { Zeolites, polymers, MOF, } \\
\text { MMM, ionic liquids, } \\
\text { adsorbents, absorbents }\end{array}$ & $\begin{array}{l}\text { (1) Carriers can form complexes with } \\
\text { gaseous components and allow the } \\
\text { facilitated transport [59]. (2) The } \\
\text { adsorption step can be followed by } \\
\text { stepwise thermal regeneration and } \\
\text { desorption [1]. }\end{array}$ & $\begin{array}{l}\text { Carriers are subject to } \\
\text { deactivation by poisonous } \\
\text { agents [59] and can be very } \\
\text { expensive [71]. }\end{array}$ \\
\hline Molecular sieving & MOF, CMS, zeolites & $\begin{array}{l}\text { (1) Molecules are separated due to } \\
\text { different molecular sizes and shapes } \\
\text { (geometrical selectivity) [8]. }\end{array}$ & $\begin{array}{l}\text { The pore diameters can be } \\
\text { significantly different from } \\
\text { characteristic sizes of } \\
\text { molecules that must be } \\
\text { separated. It may be difficult } \\
\text { to scale-up the production } \\
\text { process [59]. }\end{array}$ \\
\hline
\end{tabular}


Based on the previous paragraphs, the main objective of the present work is the development of an extensive bibliometric survey regarding the use of membranes for gas separations in petrochemical processes. In particular, it is intended to characterize the degree of maturity and the main bottlenecks of processes used for separation of light hydrocarbon mixtures containing homologous series of paraffins (methane, ethane, propane, among others) and olefins (ethene, propene, among others), focusing on ethane/ethylene and propane/propylene mixtures. Therefore, the present study also reports the membranes that are used most often, the usual process configurations, the operating conditions and the stability of the applied materials, as described in the available scientific and technical literature.

\section{Data Sources and Methodology}

The investigation of paraffin/olefin separations using membranes was performed with help of electronic search tools including Google Scholar, Google Patents, USPTO and EspaceNet. At first, screening searches were performed using the expressions "gas separation membrane(s)" and "olefin/paraffin separation membrane(s)", placed anywhere in the text. Afterwards the searches were refined with help of more specific expressions located in the title or abstract, including "membrane(s) separation(s)" AND "olefin(s)"; "membrane(s) separation(s)" AND "paraffin(s)"; "membrane(s) separation(s)" AND ("ethane" OR "C2H6"); "membrane(s) separation(s)" AND ("ethene" OR "ethylene" OR "C2H4"); "membrane(s) separation(s)" AND ("propane" OR "C3H8"); "membrane(s) separation(s)" AND ("propene" OR "propylene" $\mathrm{OR}$ "C $3 \mathrm{H}$ "). Searches were performed considering the papers published until August 2019. Then, the obtained documents were downloaded, analyzed and eventually accepted for this bibliometric survey, as described in the following paragraphs. After reading and analyzing the selected documents, additional relevant references not captured by the electronic searches were also included in the set of accepted documents. For the purposes of the present investigation, accepted documents were also used to provide information regarding the fifteen information categories listed in Table 3, which were analyzed as presented in Section 3.

Table 3. Information categories investigated in the present study.

\begin{tabular}{cccccc}
\hline$\#$ & Category & $\#$ & Category & $\#$ & Category \\
\hline 1 & Institution & 6 & Feed composition & 11 & Separated gases \\
2 & Country & 7 & Selectivity or separation factor & 12 & Type of material \\
3 & Journal & 8 & Permeability & 13 & Metal carrier \\
4 & Year of publication & 9 & Operation temperature $/{ }^{\circ} \mathrm{C}$ & 14 & Layout \\
5 & Number of citations & 10 & Operation pressure/bar & 15 & Lifetime \\
\hline
\end{tabular}

In Table 3, categories \#1 and \#2, institutions and countries, were reported considering the affiliation of the corresponding author. Category \#5, number of citations of the analyzed document, is important because it can be used to evaluate the relative relevance of the publication. Categories \#6 to \#10 (gas feed compositions, selectivities or separation factors, permeabilities, operation temperatures and operation pressures) provide information about the reported operation conditions. Categories \#11 regards the processed gaseous streams, while category \#12 describes the material used to manufacture the membranes, classified as: 12.1) polymer: polymer membranes that do not include the use of carriers or other components; 12.2) zeolite: zeolite membranes that do not include the use of carriers or other components; 12.3) facilitated transport (polymer): polymer membranes that include the use of carriers to facilitate olefin permeance through the membrane; 12.4) facilitated transport (liquid): liquid membranes that are supported by different kinds of materials, usually containing a metal carrier to facilitate the olefin transportation through the liquid solution (typically $\mathrm{AgNO}_{3}$ or $\mathrm{AgBF}_{4}$ ); 12.5) facilitated transport (hybrid): membranes that combine two or more types of materials, as composites or mixtures of polymers and inorganic matrices, and use metal carriers to facilitate olefin transportation; 12.6) CMS (carbon molecular sieve): membranes composed of pyrolyzed polymers; 12.7) MOF (metal-organic frameworks): organic or inorganic membrane matrices where metal compounds are anchored to 
facilitate transportation; 12.8) others: including absorbents, adsorbents, hybrid systems (membranes that combine two or more types of materials as composites or mixtures of polymers and inorganic matrices) and ionic liquid membranes. Category \#13 reports the metals used to facilitate the olefin transportation, whenever applicable. Category \#14 describes the geometric features of the membrane separation equipment, classified as flat sheets, spiral wounds and hollow fiber membranes. In this category, adsorption and absorption columns were also considered, as these separation strategies also constitute interesting alternatives for paraffin/olefin separations. Finally, category \#15 reports the lifetime of the analyzed membranes, one of the main concerns in the field [66].

\section{Results}

The preliminary screening search regarding "membrane gas separation" resulted in 5660 documents. After initial filtering, as mentioned in the previous section, the final set of documents comprised 300 papers (Table S3) published since the 1960s, which are analyzed below in accordance with the categories described in Table 3, which were analyzed as presented in Section 3.

From this set of documents, 236 papers regard membrane separations of gaseous streams contain studies related to mixtures between paraffins and olefins, while 64 papers regard membrane studies that analyze paraffin and/or olefin permeation (not necessarily considering their mutual separation). Thus, considering the proposed search methodology, it seems correct to say that membrane olefin/paraffin separations represent approximately $5 \%$ of the total number of papers published in this field, indicating that membrane olefin/paraffin separations do not constitute the mainstream of the area and suggesting that this technology is still under development, as reinforced in the next sections.

\subsection{The Annual Distribution}

Figures 1 and 2 present the annual distribution of publications and patents in the field of olefin/paraffin membrane separations. It must be highlighted that the first document in the analyzed field was published in 1962, regarding the separation between pentene and pentane by adsorption in solid matrixes, using charcoal as adsorber by Kellogg Company [72]. Then, in 1988, ExxonMobil published a study regarding the ethylene/ethane separation through complexation with cuprous diketonate in alpha-methyl styrene [73]. According to the methodology used in the present study, the number of papers and patents published in the field is relatively small and has not grown significantly through the years, being subject to periodic oscillations that are related to economical constraints, such as the development of shale gas technologies and the oscillation of prices of oil and gas [74]. In more recent years, the rate of scientific production increased to about 20 papers per year, due to the arousal of new technologies, such as metal-organic-frameworks (MOF) [75-80] and carbon molecular sieves (CMS) [81-87], which became more visible after 1995. When one considers the significant economic advantages that can be attained with membrane separation processes and the relatively small number of publications in this field, one can probably conclude that bottlenecks still inhibit the full industrial development of the technology.

Thomas Graham was the first to propose a description for the sorption-diffusion process in 1866 [88]. Between the years of 1940 and 1950, Barrer, van Amerongen, Meares, and others, built the fundamentals of the modern theory of gas permeation, incorporating advances of polymer sciences. The sorption-diffusion model for gas permeation, developed by Graham, continues to be a widely accepted model for the transport of gases through membranes. However, membrane manufacturing technologies have not been sufficiently robust to make membrane systems useful for separation of paraffins and olefins from gaseous streams in commercial scale, which partially justifies the lack of scientific production in the area from 1963 to 1988 [89]. Despite that, in 1989 an important paper about paraffin/olefin separations using membranes entitled "Separation of ethylene from ethane by a flowing liquid membrane using silver nitrate as a carrier" was published, reporting a new type of liquid membrane with the ability to overcome the instability and the low permeability of thin-layer liquid membranes [90]. 


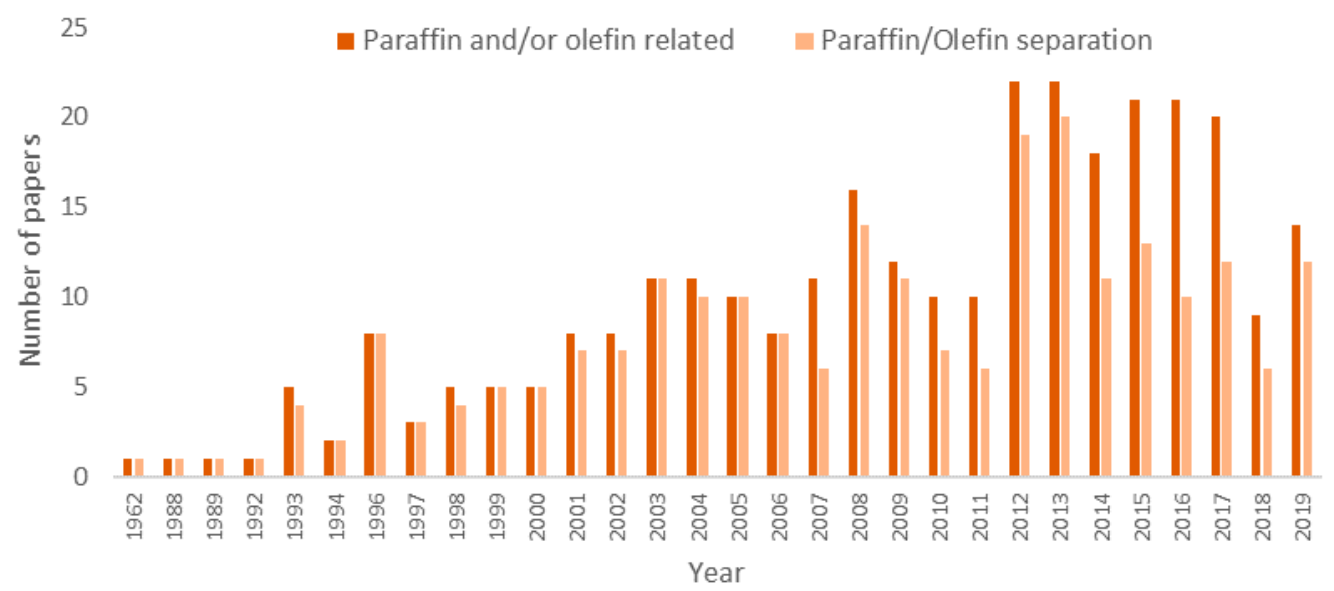

Figure 1. Annual production of papers in the field of membrane paraffin/olefin gas separations.

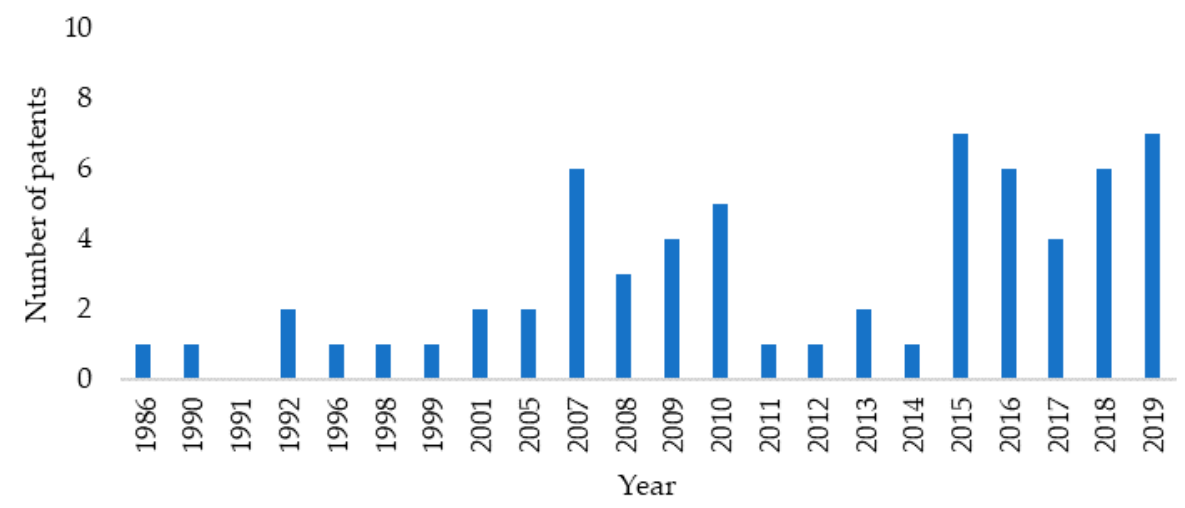

Figure 2. Annual production of patents in the field of membrane paraffin/olefin gas separations.

\subsection{The Scientific Journals Distribution}

The distribution of publications in scientific journals is shown in Table 4, for journals that published 5 or more papers in the analyzed area. As one can see, publications have been concentrated in relatively few journals, with significant concentration in Journal of Membrane Science (101 papers or 34\% of the analyzed set) and Industrial and Engineering Chemistry Research (32 papers or $11 \%$ of the analyzed set). The high quality of the journals (with IF values above 1.1) must be highlighted and indicates that this issue is regarded as relevant by the academic community. On the other hand, the extremely high concentration of papers in few journals indicates that relatively few aspects of the analyzed problem have been addressed by the scientific community, with emphasis on the production and characterization of membranes used to perform the separation of the gaseous streams.

Table 4. Distribution of papers in scientific journals in the field of membrane paraffin/olefin gas separations.

\begin{tabular}{ccccc}
\hline Ranking & Journal & IF & NP & Percentage (\%) \\
\hline 1 & Journal of Membrane Science & 6.03 & 101 & $34 \%$ \\
2 & Industrial and Engineering Chemistry Research & 2.84 & 32 & $11 \%$ \\
3 & Separation and Purification Technology & 3.35 & 14 & $5 \%$ \\
4 & Microporous and Mesoporous Materials & 3.61 & 5 & $2 \%$ \\
5 & Journal of the American Chemical Society & 13.85 & 5 & $2 \%$ \\
6 & Chemical Communications & 6.31 & 5 & $2 \%$ \\
7 & Separation Science and Technology & 1.10 & 5 & $2 \%$ \\
8 & Chemical Engineering Science & 2.89 & 5 & $2 \%$ \\
\hline
\end{tabular}

NP: Number of Publications; IF: Impact Factor. 


\subsection{The Country and Institutions Distribution}

Figure 3 and Table 5 show the country distribution of papers in the analyzed field. As a whole, the papers involved 130 institutions of 32 distinct countries, indicating the widespread interest in this area, although 6 countries concentrate more than $60 \%$ of the total number of documents of the area. Among these 6 countries, the concentration of papers in USA, Iran and China is probably related to the fact that these countries are major oil producers and present well-established refining complexes, while the concentration of papers in Netherlands and Japan probably indicates a more genuine interest of the involved institutions in the technical aspects of membrane separation technologies.

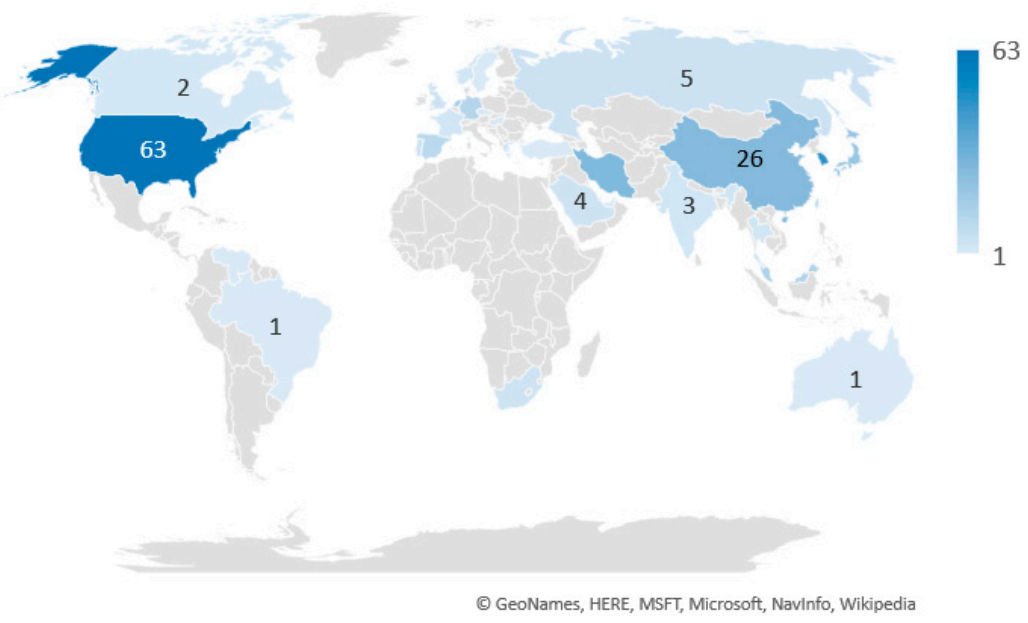

Figure 3. Country distribution of papers in the field of membrane paraffin/olefin gas separations.

Table 5. Distribution of papers in the 9 most productive countries in the field of membrane paraffin/olefin gas separations (with more than 10 papers).

\begin{tabular}{cccc}
\hline Ranking & Country & Total Publications & Percentage (\%) \\
\hline 1 & USA & 63 & $21 \%$ \\
2 & South Korea & 46 & $16 \%$ \\
3 & Iran & 27 & $9 \%$ \\
4 & China & 26 & $9 \%$ \\
5 & Japan & 20 & $7 \%$ \\
6 & Netherlands & 18 & $6 \%$ \\
7 & Malaysia & 13 & $5 \%$ \\
8 & Germany & 12 & $4 \%$ \\
9 & Spain & 10 & $4 \%$ \\
\hline
\end{tabular}

The participations of USA and Korea are also prominent in the patent area, concentrating almost $80 \%$ of all patents published in this field. When compared to published papers, France, Canada, Portugal and Saudi Arabia can be regarded as relevant developers of patents in the analyzed area (5\% of the total number of published papers and $24 \%$ of the total number of patents), despite the lower number of patents, as shown in Table 6.

Table 6. Distribution of patents in the 3 most productive countries in the field of membrane paraffin/olefin gas separations (with more than 10 patents).

\begin{tabular}{ccc}
\hline Ranking & Country & Percentage (\%) \\
\hline 1 & USA & 56 \\
2 & Korea & 21 \\
3 & France & 12 \\
\hline
\end{tabular}


The considerable contribution of South Korea, responsible for $16 \%$ of the total number of publications, may represent the efforts made by the South Korean government to support investments in research and development (RandD) related to more sustainable processes [91]. It is interesting to note that, although Japan and China are among the most productive countries in the field, Japanese and Chinese institutions are not among the most productive ones, as observed in Table 7, which indicates that Japanese and Chinese productions are shared with other international institutions.

Table 7. Distribution of papers in the 4 most productive institutions in the field of membrane paraffin/olefin gas separations (with more than 10 papers).

\begin{tabular}{|c|c|c|c|}
\hline Ranking & Institutions & Documents & Percentage (\%) \\
\hline 1 & $\begin{array}{l}\text { Korea Institute of Science and Technology } \\
\text { (South Korea) }\end{array}$ & 21 & 7 \\
\hline 2 & $\begin{array}{c}\text { Amirkabir University of Technology } \\
\text { (Iran) }\end{array}$ & 12 & 4 \\
\hline 2 & $\begin{array}{c}\text { Georgia Institute of Technology } \\
\text { (USA) }\end{array}$ & 12 & 4 \\
\hline 3 & $\begin{array}{l}\text { University of Twente } \\
\text { (The Nerthelands) }\end{array}$ & 10 & 3 \\
\hline
\end{tabular}

Table 8 presents the ranking of patent applicants. ExxonMobil, UOP, Institut Français du Petrole, Industry-University Cooperation Foundation Hanyang University and Korea Institute of Science and Technology apparently stand out as top patent applicants for paraffin/olefin separations using membranes. Despite that, the patent production does not reflect the availability of large-scale commercial facilities, although it is true that pilot plants are currently under operation in different institutions, as recently reported by Dow Chemical. It is worth mentioning that the authors of patents filed by the Korea Institute of Science and Technology are the same authors that published many of the Korean papers, which may indicate that this innovative activity is not necessarily connected with actual commercial manufacture of new membrane products [92-100].

Table 8. Distribution of patents in the 6 most productive institutions in the field of membrane paraffin/olefin gas separations.

\begin{tabular}{cccc}
\hline Ranking & Institution & Countries & Percentage (\%) \\
\hline 1 & ExxonMobil Research and Engineering Company & USA & 9 \\
1 & UOP LLC & USA & 9 \\
1 & Institut Français du Petrole & France & 9 \\
1 & Industry-University Cooperation Foundation & Korea & 9 \\
1 & Hanyang University & Korea & 9 \\
2 & Korea Institute of Science and Technology & USA & 6 \\
\hline
\end{tabular}

\subsection{The Most Cited Papers}

Table 9 shows the most cited papers in the investigated field. As one can observe, the most cited papers describe the use of different membrane materials for separation of gaseous streams that contain paraffins and olefins. This probably shows that the scientific research in this area is still driven by the necessity to develop new materials that can improve the efficiency of membrane paraffin/olefin separations. Still, it is important to note that among the most cited documents, three deal with a relatively recent membrane type, which may be an indicative that MOFs are being seen by the scientific community as promising materials for gas stream separation, specifically considering the paraffin/olefin mixture. 
Table 9. The most cited papers in the field of membrane paraffin/olefin gas separations.

\begin{tabular}{|c|c|c|c|c|c|}
\hline Ranking & Paper & Separated Gases & Type of Membrane (Name) & Citations & Ref. \\
\hline 1 & $\begin{array}{l}\text { Hydrocarbon Separations in a Metal-Organic Framework with Open } \\
\text { Iron(II) Coordination Sites } \\
\text { Authors: Bloch, E.D., Queen, W.L., Krishna, R., Zadrozny, J.M., } \\
\text { Brown, C.M., Long, J.R. } \\
\text { Source: Science (2012) }\end{array}$ & $\begin{array}{l}\text { Ethylene/Ethane } \\
\text { Propane/Propane }\end{array}$ & MOF (Fe2(dobdc)) & 1008 & [101] \\
\hline 2 & $\begin{array}{c}\text { Pushing the limits on possibilities for large scale gas separation: which } \\
\text { strategies? } \\
\text { Authors: Koros, W.J., Mahajan, R. } \\
\text { Source: Journal of Membrane Science (2000) }\end{array}$ & $\begin{array}{l}\text { Olefin/Paraffin } \\
\text { Others }\end{array}$ & Various (Review) & 829 & [102] \\
\hline 3 & $\begin{array}{c}\text { Gas solubility, diffusivity and permeability in poly(ethylene oxide) } \\
\text { Authors: Lin, H., Freeman, B.D. } \\
\text { Source: Journal of Membrane Science (2004) }\end{array}$ & $\begin{array}{l}\text { Ethylene/Ethane } \\
\text { Propylene/Propane } \\
\text { Others }\end{array}$ & Polymer (PEO) & 627 & [103] \\
\hline 4 & $\begin{array}{l}\text { Olefin/Paraffin Separation Technology: A Review } \\
\text { Author: Eldridge, R.B. } \\
\text { Source: Industrial and Engineering Chemistry Research (1993) }\end{array}$ & Olefin/Paraffin & Various (Review) & 580 & {$[1]$} \\
\hline 5 & $\begin{array}{c}\text { Application of membrane separation processes in petrochemical } \\
\text { industry: a review } \\
\text { Authors: Ravanchi, M.T., Kaghazchi, T., Kargari, A. } \\
\text { Source: Desalination (2009) }\end{array}$ & Propylene/Propane & Polymer (6FDA-DDBT) & 487 & [53] \\
\hline 6 & $\begin{array}{c}\text { Title: Zeolitic Imidazolate Frameworks for Kinetic Separation of Propane } \\
\text { and Propene } \\
\text { Author(s): Li, K., Olson, D.H., Seidel, J., Emge, T.J., Gong, H., Zeng, H., } \\
\text { Li, J. } \\
\text { Source: Journal of the American Chemical Society (2009) }\end{array}$ & Propylene/Propane & MOF (ZIF-8) & 466 & [104] \\
\hline 7 & $\begin{array}{l}\text { Title: Ethane/Ethene Separation Turned on Its Head: Selective Ethane } \\
\text { Adsorption on the Metal-Organic Framework ZIF-7 through a } \\
\text { Gate-Opening Mechanism. } \\
\text { Author(s): Gücüyener, C., Bergh, J.V.D., Gascon, J., Kapteijn, F. } \\
\text { Source: Journal of the American Chemical Society (2010) }\end{array}$ & Ethylene/Ethane & $\begin{array}{l}\text { MOF } \\
\text { (ZIF-7) }\end{array}$ & 408 & [77] \\
\hline 8 & $\begin{array}{l}\text { Title: Olefin/Paraffin Separations by Reactive Absorption: A Review } \\
\text { Author(s): Safarik, D.J., Eldridge, R.B. } \\
\text { Source: Industrial and Engineering Chemistry Research (1998) }\end{array}$ & Olefin/Paraffin & $\begin{array}{l}\text { Absorbent } \\
\text { (Review) }\end{array}$ & 312 & [105] \\
\hline
\end{tabular}




\subsection{The Separated Streams}

Based on the adopted search criteria, 322 distinct streams have been reported in the literature, being that 248 streams of them contained mixtures of paraffin/olefin and 74 of them contained other gaseous components. In the last case, membrane permeabilities of pure gaseous streams, such as single paraffins or single olefins; separations of streams containing paraffin mixtures (butane/methane, butane isomers, pentane/octane, and propane/methane, for example) or olefin mixtures (butenes, di-olefin/mono-olefin, 1-hexene/1,5-hexadiene, acetylene/ethylene, for example); and separations of olefins or paraffins from other gases, such as $\mathrm{N}_{2}$, air, argon, $\mathrm{H}_{2} \mathrm{~S}, \mathrm{CO}, \mathrm{H}_{2}$, and $\mathrm{CO}_{2}$ ' have also been reported, as summarized in Figure 4.

= Olefin/Other gases

- Olefins mixtures

- Other mixtures

- Single Gases

" Paraffins mixtures

- Paraffin/Other Gases

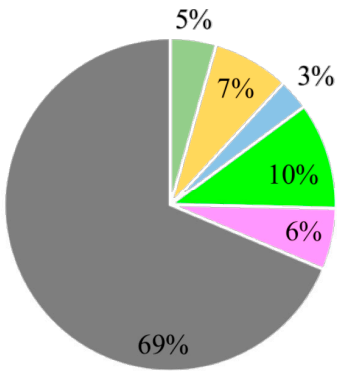

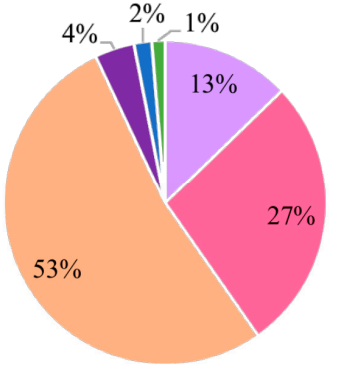

- Other $\mathrm{P} / \mathrm{O}$

- Paraffin/olefin C2

- Paraffin/olefin C3

- Paraffin/olefin C4

- Paraffin/olefin C5

- Paraffin/olefin C6

Figure 4. Streams reported in papers regarding paraffin/olefin membrane separations.

It is important to notice that the number of studies involving separations of mixtures of paraffins with other gases is expressive. Almost $85 \%$ of the publications reported in the field of membrane gas separations regard mixtures of paraffins and $\mathrm{CO}_{2}$, especially methane and $\mathrm{CO}_{2}$, due to the importance of this gaseous stream for the oil production industry and necessity to remove carbon dioxide from natural gas during oil production and enhanced oil recovery [106].

Although the present work has emphasized the separation of ethane/ethylene and propane/propylene streams, studies with other olefin and paraffin streams, strongly associated with gaseous effluents from petrochemical industries, have also been evidenced. This may be attributed to the necessity to enrich and utilize certain valuable chemicals, such as isobutene (in isobutene/isobutane mixtures), 1,3-butadiene (in 1,3-butadiene//n-butane mixtures), 1-heptene (in heptene/heptane mixtures), 1-hexene (in hexene/hexane mixtures), 1-pentene (in pentene/pentane mixtures), cyclohexene (in cyclohexene/cyclohexane mixtures), among others, with help of technologies that can be more efficient than conventional distillation processes.

The collected data set was filtered and is available as Supplementary Material. Table S1 shows the reported membranes and the separation factors for some gaseous streams containing paraffins and/or olefins. Table S2 displays some papers that present detailed geometric configurations and operation conditions for olefin/paraffin membrane separations, with emphasis on separations of ethane/ethylene and propane/propylene streams.

\subsection{The Used Membranes}

Membranes have been successfully employed for separations of many liquid streams [107] and many specific gaseous streams, such as mixtures of $\mathrm{H}_{2}, \mathrm{CO}_{2}$ and $\mathrm{CH}_{4}$, known as "fast gases" or gases with high permeations [108]. AirLiquide ${ }^{\circledR}$, Schlumberger ${ }^{\circledR}$, Generon ${ }^{\circledR}$, AirProducts ${ }^{\circledR}$, among others, are companies that provide commercial membranes for separation of these fast gases. However, membrane paraffin/olefin separation technologies are not consolidated yet, so that process development is still in the pilot scale phase in most cases. Particularly, researchers observed a long time ago that addition of a carrier to the membrane material might lead to higher selectivities and permeabilities, constituting a major advance in the area $[4,109]$. As observed in the analyzed papers, $55 \%$ of the papers used some type of carrier to facilitate the separation process, indicating a tendency to adopt Facilitated Transport Membranes (FTM) for paraffin/olefin separations [8]. The carrier is expected to interact 
with one component of the gaseous stream (usually the olefin), increasing the apparent solubility and permeability of the compound in the membrane material $[8,110]$. Usually, the carrier contains a metal atom with free valences that make possible the electronic interaction with the electronic cloud of the carbon double bond of olefins [8,111-113].

Figure 5 presents the schematic representation of the evolution of membrane technology. Facilitated transport membranes (where the use of a carrier increases the membrane selectivities) initially displaced conventional polymer membranes because of the best separation performances. However, the search for even better separation coefficients and dynamic stability opened room for introduction of zeolites, carbon molecular sieve membranes (CMSs) and metal-organic frameworks (MOFs). Although the use of CMSs, MOFs and zeolites for olefin/paraffin separations was modest until the 2000s, as observed in Figure 6, these latest technologies have been extensively studied for 15-20 years and seem promising for paraffin/olefin separation applications. Despite that, it is still necessary to enhance important properties, such as mechanical resistance, performance stability and production cost, for large-scale industrial applications to become technically and economically viable in the field of membrane paraffin/olefin separations.

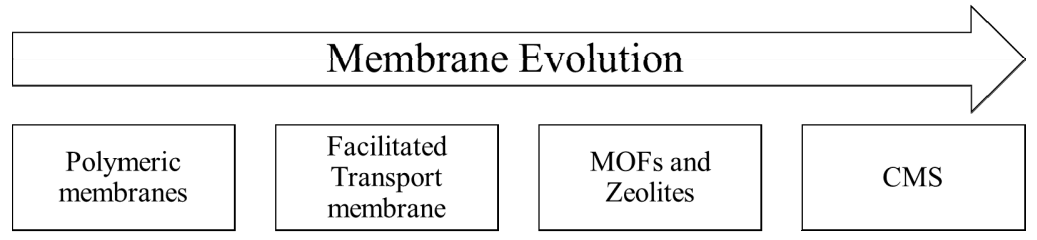

Figure 5. Schematic representation of the evolution of membrane systems used for paraffin/olefin separations.

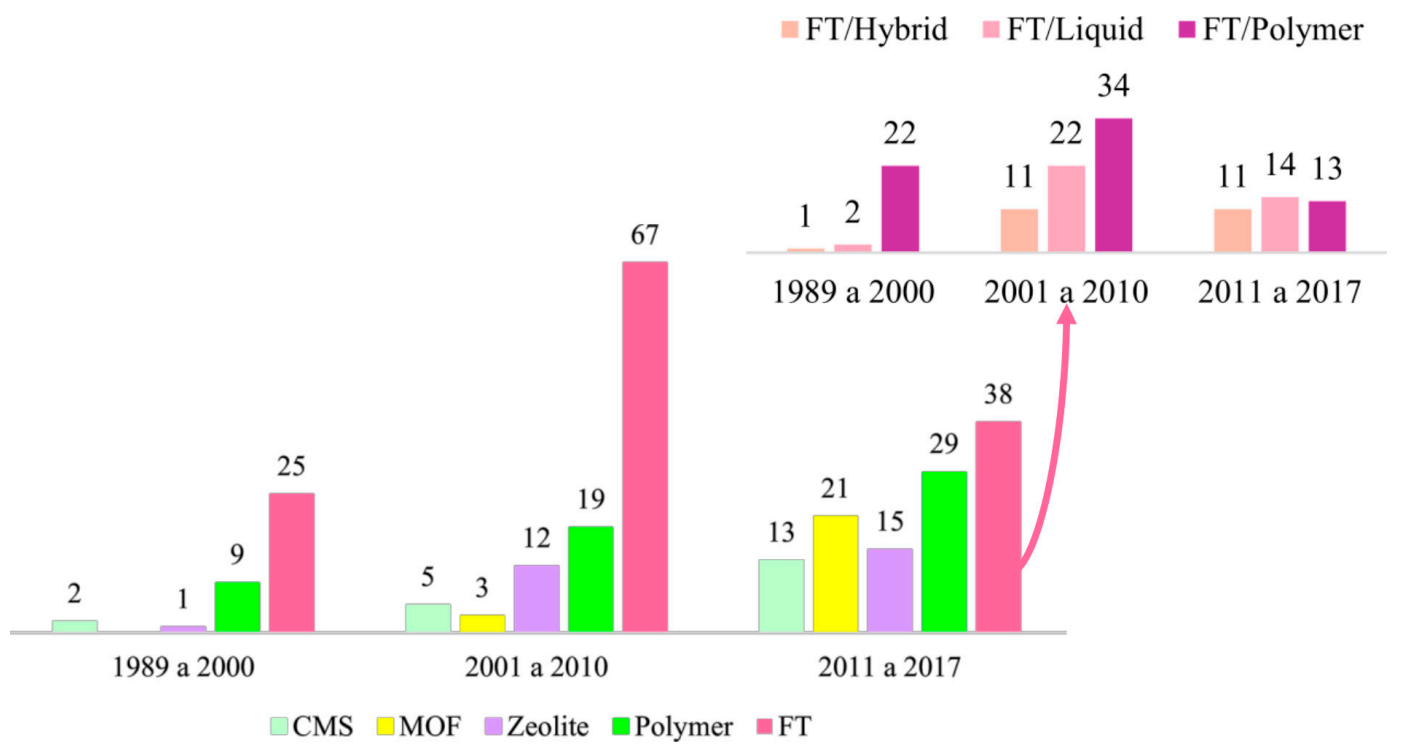

Figure 6. Types of membranes reported in papers regarding paraffin/olefin membrane separations.

Facilitated transport has been the most cited mechanism in the analyzed literature, even after the advent of new technologies. Figure 6 indicates that most of these studies (44\%) proposed the addition of a carrier agent into a polymer matrix, leading to synergetic effects between the solution-diffusion process and the chemical interaction between the olefin and the membrane through complexation of the carrier agent (as illustrated in Figure 7). Table S2 presents the relevant data collected and the main FT membranes used for olefin/paraffin separations.

FTM was originally introduced by Scholander in 1960, for purification of $\mathrm{O}_{2}$ streams [114], and has been intensively studied since then [114,115]. FTM enables the selective transportation of molecules and explores reversible chemical interactions between the target species and the active sites (carriers) 
to accomplish the transport of the target molecule through the membrane matrix, leading to enhanced membrane permeability and selectivity. Meanwhile, other species that do not react with the active sites permeate through the membrane only through the usual solution-diffusion mechanism [116-118]. Figure 6 illustrates the effect of the carrier on the transport through the membrane.

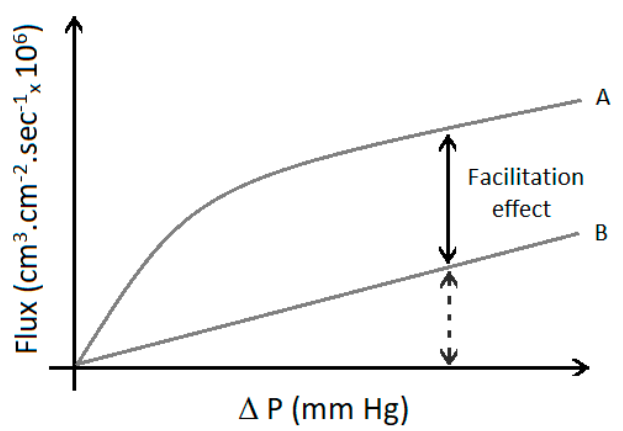

Figure 7. Effect of facilitated transport through the membrane: solute diffusion using (A) FTM and (B) carrier-free membrane. (Adapted from [119].).

GALIZIA and co-workers (2017) [116] stated that it is possible to achieve superior separation properties using membranes based on facilitated transport mechanisms for many blends that are difficult to separate, such as mixtures of paraffins and olefins and of aromatic compounds [120]. Most FTM separation processes usually make use of silver as the carrier, which can interact specifically with the olefin. The ability of olefins to form reversible organometallic complexes with some transition metal cations, such as $\mathrm{Ag}^{+}$ions, ensures the separation process [1,121]. Based on the olefin complexation theory, FAIZ and LI (2012) [65] observed that the use of metals for complexation with olefins could lead to efficient separation of gaseous mixtures of paraffins and olefins. The high stability of metal-olefin complexes can be explained by interactions between the atomic orbitals of the metallic atom and the molecular orbitals of the olefin molecules, as postulated by Dewar using the Molecular Orbital Theory [105]. The bonds formed in the complex are stronger than Van der Waals forces, but still sufficiently weak to break by temperature increase or pressure reduction [121,122], making the reversible reaction possible.

In order to increase the reversible reactivity of the transition metal ion with olefins, the anion of the transition metal plays an important role in determining the intensity and the rate of the interaction between the carrier and olefins. Due to the lower lattice energy of the transition metal salt, the anion forms a weak ionic bond or ion pair with the cation and the salt can be easily dissolved in solutions. Therefore, it is preferable to select a transition metal anion that possesses low lattice energy in respect to the metal cation [123]. For facilitated transport to occur, the lattice energy of the transition metal salt must be preferably smaller than $1000 \mathrm{~kJ} / \mathrm{mol}$, reducing the tendency of the anion of the transition metal salt to form a strong ion pair with the cation $[123,124]$.

Based on criteria reported usually in the literature for effective FTM processes, including electronegativity, lattice energy and intensity of $\pi$-complexation between metals and olefins, silver salt has been largely selected as the most appropriate carrier for facilitated transport of olefins. The commonest generalized and overall reaction scheme for the transport of olefins across the membrane is shown in Equation (1) [1,117,118,123]:

$$
\text { Olefin }+\mathrm{Ag}^{+} \rightleftharpoons\left[\text { Olefin. } \mathrm{Ag}^{+}\right]
$$

RAVANCHI (2015) [118] studied the influence of carrier concentration on propylene/propane separation using hydrophilic poly(vinylidene difluoride) ( $\left.\mathrm{Ag}^{+} / \mathrm{PVDF}\right)$ flat sheet membranes. The author concluded that it is important to consider three parameters simultaneously for process design: trans-membrane pressure, carrier concentration and effect of feed composition on the separation factor. It is important to highlight that facilitated transport is a combination of two processes: absorption (on 
the feed side) and stripping (on the permeate side). Increasing the pressure favors absorption and decreasing the pressure favors stripping. Thus, increasing the feed pressure increases the absorbed olefin on the feed side. Due to the pressure difference between the feed side and the permeate side, the olefin complex must be degraded on the permeate side. Therefore, increasing the transmembrane pressure enhances the driving force for separation. Besides, the separation factor and olefin permeability can be increased when higher concentrations of $\mathrm{Ag}^{+}$ions (ranging from 5 to $20 \mathrm{wt} \%$ ) are used. Table 10 presents the membranes and respective selectivities reported to separate olefin/paraffin employing facilitated transport mechanism.

Table 10. Characteristic FTM parameters for different carriers in membrane paraffin/olefin separations of gaseous streams.

\begin{tabular}{|c|c|c|c|c|c|}
\hline Separated Gases & $\begin{array}{l}\text { Type of } \\
\text { Material }\end{array}$ & Name of the Material & Carrier & Selectivity or Sep Factor & Ref. \\
\hline ethylene/ethane & FT/Hybrid & not specified & $\mathrm{Ag}$ & NS & [125] \\
\hline ethylene/ethane & FT/Hybrid & not specified & $\mathrm{Ag}^{+}$ & SF 65 ethylene/ethane & [126] \\
\hline ethylene/ethane & FT/Hybrid & Chitosan/Ag (Imtex) & $\mathrm{Ag}^{+}$ & SF 100 ethylene/ethane & [127] \\
\hline ethylene/ethane & FT/Hybrid & $5 \mathrm{~A}$ zeolite & $\mathrm{Ag}^{+}$ & S 27.4 ethylene & [128] \\
\hline ethylene/ethane & FT/Hybrid & $\mathrm{Fe} 2($ dobdc) & $\mathrm{Ag}^{+}$ & S 13.6 ethylene & [128] \\
\hline ethylene/ethane & FT/Liquid & $\mathrm{PEO} / \mathrm{PBT} / \mathrm{AgNO}_{3}$ & $\mathrm{Ag}^{+}$ & SF 165 ethylene/ethane & [130] \\
\hline ethylene/ethane & FT/Liquid & EPDM-SPEEK & $\mathrm{Ag}^{+}$ & SF 2700 ethylene/ethane & [131] \\
\hline ethylene/ethane & FT/Liquid & [4-mebupy $] \mathrm{BF}_{4}$ & $\mathrm{Ag}^{+}$ & S 3 ethylene & [132] \\
\hline ethylene/ethane & FT/Liquid & Cu SILM supported PVDF & $\mathrm{Cu}$ & S 11.8 & [133] \\
\hline ethylene/ethane & FT/Liquid & PIL/40IL-Ag ${ }^{+} 1.25 \mathrm{M}$ & $\mathrm{Ag}^{+}$ & S 7.24 etylene & [134] \\
\hline ethylene/ethane & FT/Liquid & $\mathrm{ZnCl}_{2} /[\mathrm{BMIM}][\mathrm{Cl}]$ & $\mathrm{Zn}$ IL & S 178 & [135] \\
\hline ethylene/ethane & FT/Polymer & Nafion N-117 & $\mathrm{Ag}^{+}$ & SF 540 ethylene/ethane & [137] \\
\hline ethylene/ethane & FT/Polymer & $\mathrm{AgBF}_{4} / \mathrm{PVP}$ & $\mathrm{Ag}^{+}$ & SF 2.3 ethylene/ethane & [138] \\
\hline ethylene/ethane & FT/Polymer & $\mathrm{AgBF}_{4} / \mathrm{PEO}$ & $\mathrm{Ag}^{+}$ & SF 240 ethylene/ethane & [139] \\
\hline ethylene/ethane & FT/Polymer & Pebax®4011 and Pebax®2533 (Atofina) & $\mathrm{Ag}^{+}$ & NS & [140] \\
\hline ethylene/ethane & FT/Polymer & $\mathrm{AgNO}_{3} /$ polyethersulfone (Daicel) & $\mathrm{Ag}^{+}$ & SF 1100 ethylene/ethane & [141] \\
\hline ethylene/ethane & FT/Polymer & PA $12-\mathrm{PTMO} / \mathrm{AgBF}_{4}$ & $\mathrm{Ag}^{+}$ & SF 20 ethylene/ethane & [142] \\
\hline ethylene/Ethane & FT/Polymer & $\mathrm{POZ} \mathrm{AgBF}_{4}$ & $\mathrm{Ag}^{+}$ & SF 5 ethylene/ethane & [143] \\
\hline ethylene/ethane & FT/Polymer & EPDM & $\mathrm{Ag}^{+}$ & SF 72.5 ethylene/ethene & [136] \\
\hline ethylene/ethane & FT/Polymer & $\mathrm{AgNO}_{3} /$ polyethersulfone (Daicel) & $\mathrm{Ag}^{+}$ & SF 374 ethylene/ethane & [144] \\
\hline ethylene/ethane & FT/Polymer & PebaxTM 2533/AgBF 4 & $\mathrm{Ag}^{+}$ & NS & [145] \\
\hline ethylene/ethane & FT/Polymer & $3 c$ & $\mathrm{Ag}^{+}$ & SF 115 ethylene/ethane & [146] \\
\hline ethylene/ethane & FT/Polymer & $\mathrm{SiO}_{2}$ Poly(sodium acrylate) $\mathrm{Ag}^{+}$ & $\mathrm{Ag}^{+}$ & SF 94 ethylene/ethane & [147] \\
\hline propylene/propane & FT/Hybrid & $\mathrm{Ag} / \mathrm{c}-\mathrm{Al}_{2} \mathrm{O}_{3}$ & $\mathrm{Ag}^{+}$ & S 1.2 propane & [153] \\
\hline propylene/propane & FT/Hybrid & $\begin{array}{c}\mathrm{POZ} / \mathrm{AgNO}_{3} / \mathrm{SiO}_{2} \text { (fumed silica } \\
\text { nanoparticles) }(1: 1: 0.1)\end{array}$ & $\mathrm{Ag}^{+}$ & S 90.0 propylene/propane & [154] \\
\hline propylene/propane & FT/Hybrid & $\mathrm{POZ} / \mathrm{AgNO}_{3} / \mathrm{BMIM}^{+} \mathrm{NO}_{3}^{-}$ & $\mathrm{Ag}^{+}$ & S 32.0 propylene/propane & [155] \\
\hline propylene/propane & FT/Hybrid & $\mathrm{POZ} / \mathrm{AgNO}_{3} / \mathrm{BMIM}^{+} \mathrm{BF}_{4}^{-}$ & $\mathrm{Ag}^{+}$ & S 31.8 propylene/propane & [155] \\
\hline propylene/propane & FT/Hybrid & $\mathrm{POZ} / \mathrm{AgNO}_{3} / \mathrm{BMIM}^{+} \mathrm{CF}_{3} \mathrm{SO}_{3}{ }^{-}$ & $\mathrm{Ag}^{+}$ & S 33.2 propylene/propane & [155] \\
\hline propylene/propane & FT/Hybrid & PVP/Nano Au (Seahan) & $\mathrm{Au}$ & S 22 propylene & [96] \\
\hline propylene/propane & FT/Hybrid & $\mathrm{POZ}$ & $\mathrm{Ag}^{+}$ & SF 20-22.5 propylene/propane & [156] \\
\hline propylene/propane & FT/Hybrid & PVDF-HFP/BMImBF $4{ }^{-} \mathrm{Ag}^{+}$ & $\mathrm{Ag}^{+}$ & S 700 propane & [157] \\
\hline propylene/propane & FT/Hybrid & $\mathrm{AgNO}_{3} / \mathrm{Al}_{2} \mathrm{O}_{3}$ & $\mathrm{Ag}^{+}$ & NS & [158] \\
\hline propylene/propane & FT/Hybrid & MICRODYN MD020 TP 2N & $\mathrm{Ag}^{+}$ & NS & [159] \\
\hline propylene/propane & FT/Hybrid & $\mathrm{TiO}_{2}-\mathrm{PEO}-\mathrm{AgBF}_{4}$ & $\mathrm{Ag}^{+}$ & S 19 propylene/propane & [160] \\
\hline propylene/propane & FT/Hybrid & Permylene (Imtex) & $\mathrm{Ag}^{+}$ & NS & [161] \\
\hline propylene/propane & FT/Hybrid & PHMEP-g-PEGBEM/AgBF $4 / \mathrm{MgO}-\mathrm{NS}$ & $\mathrm{Ag}^{+}$ & SF 12.9 propylene/ propane & [162] \\
\hline propylene/propane & FT/Liquid & $\mathrm{POZ} / \mathrm{AgNO}_{3} / \mathrm{BMIM}^{+} \mathrm{BF}_{4}^{-}$ & $\mathrm{Ag}^{+}$ & SF 31.8 propylene/propane & [163] \\
\hline propylene/propane & FT/Liquid & $\mathrm{POZ} / \mathrm{AgNO}_{3} / \mathrm{BMIM}^{+} \mathrm{NO}_{3}^{-}$ & $\mathrm{Ag}^{+}$ & SF 32 propylene/propane & [163] \\
\hline propylene/propane & FT/Liquid & zirconia/ $\mathrm{AgNO}_{3}$ & $\mathrm{Ag}^{+}$ & SF 20 propylene/propane & [164] \\
\hline propylene/propane & FT/Liquid & TEG/AgBF 4 & $\mathrm{Ag}^{+}$ & SF 60 propylene/propane & [165] \\
\hline
\end{tabular}


Table 10. Cont.

\begin{tabular}{|c|c|c|c|c|c|}
\hline Separated Gases & $\begin{array}{l}\text { Type of } \\
\text { Material }\end{array}$ & Name of the Material & Carrier & Selectivity or Sep Factor & Ref. \\
\hline propylene/propane & FT/Liquid & $\mathrm{AgBF}_{4}$ & $\mathrm{Ag}^{+}$ & S 4.5 propylene & [166] \\
\hline propylene/propane & FT/Liquid & PVDF/AgNO 3 & $\mathrm{Ag}^{+}$ & SF 474 propylene/propane & [167] \\
\hline propylene/propane & FT/Liquid & $\mathrm{BMIM}^{+} \mathrm{BF}_{4}^{-} / \mathrm{Ag}$ & $\mathrm{Ag}^{+}$ & SF 17 propylene/propane & [168] \\
\hline propylene/propane & FT/Liquid & Ag-BMImBF 4 & $\mathrm{Ag}^{+}$ & NS & [169] \\
\hline propylene/propane & FT/Liquid & $\mathrm{AgNO}_{3} / \mathrm{PVDF}$ (Millipore) & $\mathrm{Ag}^{+}$ & NS & [170] \\
\hline propylene/propane & FT/Liquid & $\mathrm{BMIM}^{+} \mathrm{BF}_{4}^{-}$ & $\mathrm{Cu}$ & SF 5.2 propylene/propane & [93] \\
\hline propylene/propane & FT/Liquid & $\mathrm{PVDF} / \mathrm{AgNO}_{3}$ & $\mathrm{Ag}^{+}$ & SF 480 propylene/propane & [171] \\
\hline propylene/propane & FT/Liquid & $\mathrm{PVDF} / \mathrm{AgNO}_{3}$ & $\mathrm{Ag}^{+}$ & SF 490 propylene/propane & [172] \\
\hline propylene/propane & FT/Liquid & [Ag(propene)x][Tf2N] & $\mathrm{Ag}^{+}$ & SF 3 propane/propene & [173] \\
\hline propylene/propane & FT/Liquid & RTILs & $\mathrm{Ag}^{+}$ & SF 100 propylene/propane & [174] \\
\hline propylene/propane & FT/Liquid & $\mathrm{PVDF} / \mathrm{AgNO}_{3}$ & $\mathrm{Ag}^{+}$ & SF 270 propylene/propane & [175] \\
\hline propylene/propane & FT/Liquid & $\mathrm{BMImBF}_{4}$ & $\mathrm{Ag}^{+}$ & SF 20 propylene/propane & [176] \\
\hline propylene/propane & FT/Liquid & $\mathrm{MOIM}^{+} \mathrm{NO}_{3}^{-}$ & IL & SF 2.8 propylene/propane & [99] \\
\hline propylene/propane & FT/Liquid & $\mathrm{BMIM}^{+} \mathrm{BF}_{4}^{-}$ & IL & SF 2.3 propylene/propane & [99] \\
\hline propylene/propane & FT/Liquid & $\mathrm{AgNO}_{3}$ in hollow fiber membrane & $\mathrm{Ag}^{+}$ & $75 \%$ propylene removal & [177] \\
\hline propylene/propane & FT/Liquid & $(\mathrm{Emim}, \mathrm{Ag})\left[\mathrm{BF}_{4}\right]^{-} \mathrm{PICPM}^{+} \mathrm{PF}_{6}^{-}$ & $\mathrm{Ag}^{+}$ & SF 7 propylene/propane & [178] \\
\hline propylene/propane & FT/Liquid & $\left(\right.$ Emim,Ag) $[\mathrm{Tf} 2 \mathrm{~N}]^{-} \mathrm{PICPM}^{+} \mathrm{Tf}^{-} \mathrm{N}^{-}$ & $\mathrm{Ag}^{+}$ & SF 7 propylene/propane & [178] \\
\hline propylene/propane & FT/Liquid & (Emim,Ag)[Tf2N]-12HSA & $\mathrm{Ag}^{+}$ & SF 7 propylene/propane & [178] \\
\hline propylene/propane & FT/Liquid & $\mathrm{MOIM}^{+} \mathrm{BF}_{4}^{-} / \mathrm{Cu}$ & $\mathrm{Cu}$ & SF 2 propylene/propane & [179] \\
\hline propylene/propane & FT/Liquid & PVDF/AgNO 3 & $\mathrm{Ag}^{+}$ & SF 473.86 propylene/propane & [118] \\
\hline propylene/propane & FT/Liquid & NMP & $\mathrm{Ag}^{+}$ & S 4.5 propylene & [180] \\
\hline propylene/propane & FT/Polymer & PVA/AgSbF 6 & $\mathrm{Ag}^{+}$ & S 125 propylene & [181] \\
\hline propylene/propane & FT/Polymer & PVDFHFP/BMImBF $4 / \mathrm{AgBF}_{4}$ & $\mathrm{Ag}^{+}$ & NS & [182] \\
\hline propylene/propane & FT/Polymer & PE-g-AA-Ag ${ }^{+}$ & $\mathrm{Cu}$ & SF 21 propylene/propane & [60] \\
\hline propylene/propane & FT/Polymer & $\mathrm{PPO}$ & $\mathrm{Ag}^{+}$ & SF 5.33 propylene/propane & [183] \\
\hline propylene/propane & FT/Polymer & $\mathrm{Cu} / \mathrm{PVP}$ & $\mathrm{Cu}$ & SF 10 propylene/propane & [184] \\
\hline propylene/propane & FT/Polymer & $\mathrm{AgNO}_{3} / \mathrm{PEG} / \mathrm{Psf}$ & $\mathrm{Ag}^{+}$ & SF 250 propylene/propane & [185] \\
\hline propylene/propane & FT/Polymer & $\mathrm{AgBF}_{4}-\mathrm{PVP}$ & $\mathrm{Ag}^{+}$ & SF 140 propylene/propane & [124] \\
\hline propylene/propane & FT/Polymer & POZ & $\mathrm{Ag}^{+}$ & SF 280 proylene/propane & [186] \\
\hline propylene/propane & FT/Polymer & PEO & $\mathrm{Ag}^{+}$ & NS & [187] \\
\hline propylene/propane & FT/Polymer & $\mathrm{AgBF}_{4}-\mathrm{PVP}$ & $\mathrm{Ag}^{+}$ & SF 140 propylene/propane & [188] \\
\hline propylene/propane & FT/Polymer & $\mathrm{AgBF}_{4}-\mathrm{POZ}$ & $\mathrm{Ag}^{+}$ & SF 130 propylene/propane & [188] \\
\hline propylene/propane & FT/Polymer & $\mathrm{PVP} / \mathrm{AgBF}_{4}$ & $\mathrm{Ag}^{+}$ & NS & [189] \\
\hline propylene/propane & FT/Polymer & $\mathrm{PVP} / \mathrm{AgBF}_{4}$ & $\mathrm{Ag}^{+}$ & SF 60 propylene/propane & [190] \\
\hline propylene/propane & FT/Polymer & $\mathrm{PVP} / \mathrm{AgNO}_{3} / \mathrm{Ppy}$ & $\mathrm{Ag}^{+}$ & NS & [191] \\
\hline propylene/propane & FT/Polymer & POZ & $\mathrm{Ag}^{+}$ & SF 5 propylene/propane & [192] \\
\hline propylene/propane & FT/Polymer & $\mathrm{PEP} / \mathrm{AgBF}_{4}$ & $\mathrm{Ag}^{+}$ & SF 55 propylene/propane & [94] \\
\hline propylene/propane & FT/Polymer & $\mathrm{PDMS}_{\mathrm{AgBF}}$ & $\mathrm{Ag}^{+}$ & SF 200 propylene/propane & [193] \\
\hline propylene/propane & FT/Polymer & PHMV & $\mathrm{Ag}^{+}$ & S 336 propylene & [194] \\
\hline propylene/propane & FT/Polymer & POZ & $\mathrm{Ag}^{+}$ & SF 65 propylene/propane & [195] \\
\hline propylene/propane & FT/Polymer & PVP/silver salts & $\mathrm{Ag}^{+}$ & NS & [196] \\
\hline propylene/propane & FT/Polymer & $\mathrm{POZ} / \mathrm{AgBF}_{4}$ & $\mathrm{Ag}^{+}$ & SF 45 propylene/propane & [197] \\
\hline propylene/propane & FT/Polymer & 6FDA-4MPD/DABA & $\mathrm{Ag}^{+}$ & S 10 propylene/propane & [198] \\
\hline propylene/propane & FT/Polymer & $\mathrm{BMIM}^{+} \mathrm{BF}_{4}$ & $\mathrm{Ag}^{+}$ & SF 17 propylene/propane & [95] \\
\hline propylene/propane & FT/Polymer & SBS $/ 0.5 \mathrm{Ag}$ & $\mathrm{Ag}^{+}$ & S 80 propylene/propane & [199] \\
\hline propylene/propane & FT/Polymer & Ag-sugar/BMIM ${ }^{+} \mathrm{BF}_{4}^{-}(0.05 / 1)$ & $\mathrm{Ag}^{+}$ & SF 12.9 propylene/propane & [200] \\
\hline propylene/propane & FT/Polymer & PVC-g-P4VP & $\mathrm{Ag}^{+}$ & S 6 propylene & [201] \\
\hline propylene/propane & FT/Polymer & PEI/Pebax2533/AgBF 4 & $\mathrm{Ag}^{+}$ & SF 1000 propylene/propane & [202] \\
\hline propylene/propane & FT/Polymer & $\mathrm{PU} / \mathrm{AgCF}_{3} \mathrm{SO}_{3}$ (BASF ) & $\mathrm{Ag}^{+}$ & S 10 propylene & [203] \\
\hline propylene/propane & FT/Polymer & PTFE (Mencor) & $\mathrm{Ag}^{+}$ & $60 \%$ propylene & [121] \\
\hline propylene/propane & FT/Polymer & $\mathrm{PP} / \mathrm{AgBF}_{4}$ & $\mathrm{Ag}^{+}$ & NS & [204] \\
\hline propylene/propane & FT/Polymer & $\begin{array}{l}\text { polymer membranes with inorganic } \\
\text { nanoparticles uniformly dispersed }\end{array}$ & $\mathrm{Zn}$ & SF 18.08 propylene/propane & [205] \\
\hline propylene/propane & FT/Polymer & Pebax@1657/AgBF 4 (Atofina) & $\mathrm{Ag}^{+}$ & SF 20.4 propylene/propane & [206] \\
\hline propylene/propane & FT/Polymer & poly(vinylalcohol)/AgBF $4 / \mathrm{Al}\left(\mathrm{NO}_{3}\right)_{3}$ & $\mathrm{Ag}^{+}$ & SF 17 propylene/propane & [98] \\
\hline propylene/propane & FT/Polymer & $(\mathrm{PVA}) / \mathrm{AgBF}_{4} / \mathrm{Al}\left(\mathrm{NO}_{3}\right)_{3}$ & $\mathrm{Ag}^{+}$ & NS & [98] \\
\hline propylene/propane & FT/Polymer & $\mathrm{PVP} / \mathrm{AgBF}_{4} / \mathrm{Al}\left(\mathrm{NO}_{3}\right)_{3} / \mathrm{Ag}_{2} \mathrm{O}$ & $\mathrm{Ag}^{+}$ & SF 21.7 propylene/propane & [100] \\
\hline propylene/propane & FT/Polymer & CAF (CMS) & $\mathrm{Ag}^{+}$ & SF 50 propylene/propane & [207] \\
\hline propylene/propane & FT/Polymer & SBS/Cu@MIL-101(Cr) MMM & $\mathrm{Cu}$ & S 2 propylene & [208] \\
\hline propylene/propane & FT/Polymer & PE-g-AA-Ag ${ }^{+}$ & $\mathrm{Ag}^{+}$ & S 5 propane & [209] \\
\hline propylene/propane & FT/Polymer & PE-g-AA-Cu ${ }^{+}$ & $\mathrm{Cu}^{+}$ & S 2.2 propane & [209] \\
\hline propylene/propane & FT/Polymer & PE-g-AA-Cu ${ }^{2+}$ & $\mathrm{Cu}^{2+}$ & S 1.7 propane & [209] \\
\hline propylene/propane & FT/Polymer & PEO-AgBF 4 & $\mathrm{Ag}^{+}$ & NS & [151] \\
\hline
\end{tabular}

The separation factor (SF) of the gas pairs may be defined as the quotient between the molar ratios of the components in the permeate side divided by the quotient between the molar ratios of the components in the feed side. The ideal selectivity $(\mathrm{S})$ is calculated as the ratio between the permeances of the individual components. NS stands for not specified. 
When compared to FT, the use of other technologies (Figure 8) is relatively less frequent, including the use of adsorbents [72,73,105,210-212], liquid membranes [41,48] and hybrid membranes $[17,29,213,214]$, which were grouped as "Others" and concentrate $10 \%$ of the papers. The relatively large number of alternative membrane technologies indicate that researchers and technicians are still searching for an efficient and viable membrane system for separation of gaseous paraffin/olefin mixtures.

In 1996, it was reported that carbonized membranes produced with different materials might present higher permeabilities and selectivities than the non-carbonized precursor polymers [81]. Table 11 presents selectivities, permeabilities and operating conditions reported for gas separations using CMS membranes. When the numbers presented in Table 11. Reference values reported for gas separations with help of CMS membranes are compared to each other, it becomes possible to observe the high variability of the reported results, which makes difficult the definition of operation conditions and performance indexes for these systems.

Table 11. Reference values reported for gas separations with help of CMS membranes.

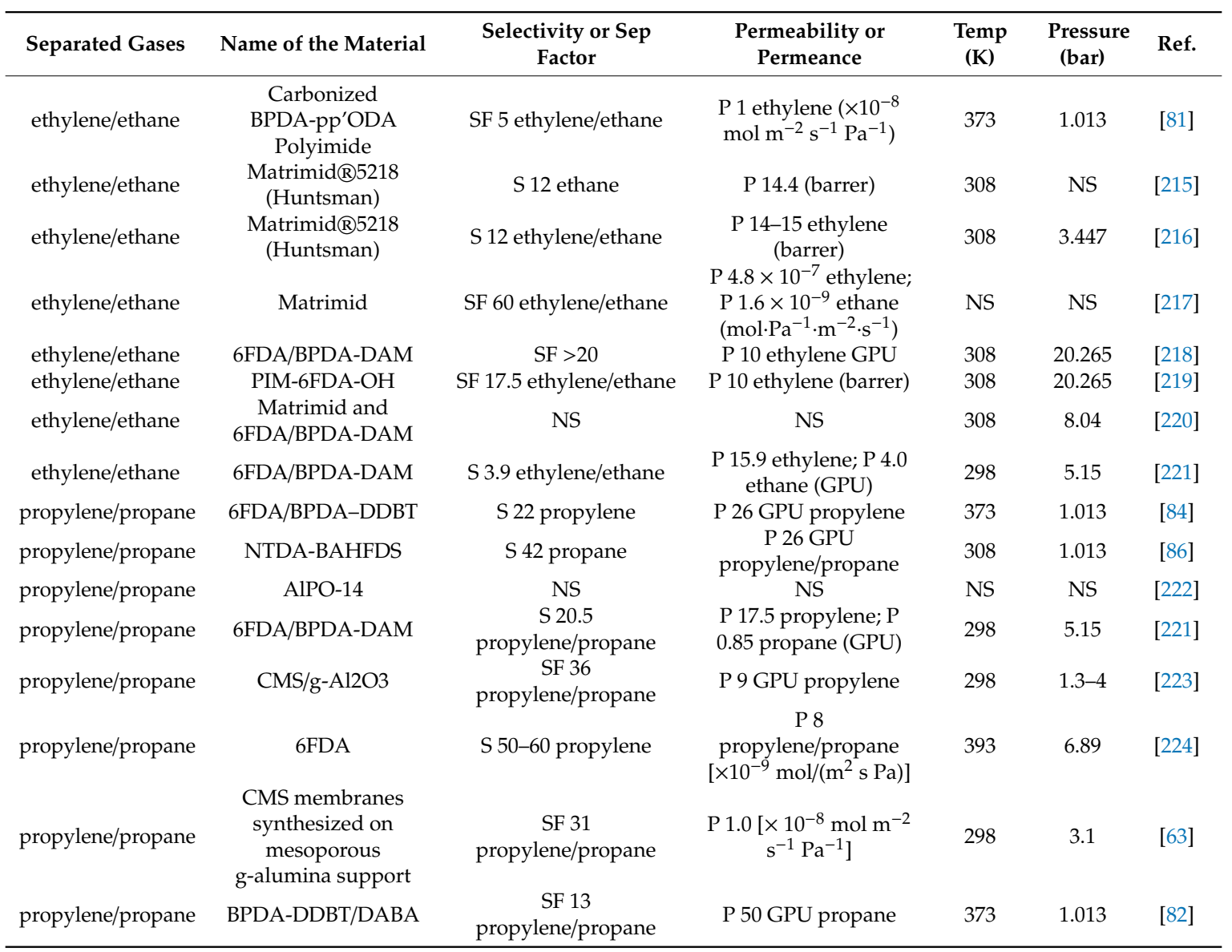

The uses of zeolite and MOF membranes for separation of gaseous paraffin/olefin streams are presented in Table 12. The separation mechanism of the molecules is based mainly on the molecular sizes and shapes (geometrical selectivity) [52]. The studies have shown superior selectivity in MOF membranes. Special attention must be given to the membrane MIL-100(Fe), prepared in lab-scale with BET surface area of $2558 \mathrm{~m}^{2} \cdot \mathrm{g}^{-1}$, which provided selectivities of 111 and 70 at $1 \mathrm{kPa}$ and room temperature for ethylene/ethane and propylene/propane separations, respectively [225]. 
Table 12. Reference values reported for gas separations using zeolite and MOF membranes.

\begin{tabular}{|c|c|c|c|c|c|c|}
\hline Separated Gases & Name of the Material & $\begin{array}{l}\text { Selectivity or Sep } \\
\text { Factor }\end{array}$ & $\begin{array}{l}\text { Permeability or } \\
\text { Permeance }\end{array}$ & $\begin{array}{l}\text { Temp } \\
\text { (K) }\end{array}$ & $\begin{array}{l}\text { Pressure } \\
\text { (bar) }\end{array}$ & Ref. \\
\hline ethylene/ethane & $\begin{array}{l}\text { CuCl-modified } \\
\text { tubular } \gamma-\mathrm{Al}_{2} \mathrm{O}_{3} \\
\text { membrane }\end{array}$ & SF 1.4 ethylene/ethane & NS & 333 & 2.026 & [226] \\
\hline ethylene/ethane & $\mathrm{CuCl} / \mathrm{NaX}$ & NS & NS & 358 & 2 & [227] \\
\hline ethylene/ethane & Na-ETS-10 & S 5 ethylene & NS & 298 & 1.013 & [228] \\
\hline ethylene/ethane & $\mathrm{AgA}$ and $\mathrm{AgX}$ & NS & NS & 303 & 1.013 & [229] \\
\hline ethylene/ethane & ZIF-4 and ZIF-zni & NS & NS & 293 & NS & [230] \\
\hline ethylene/ethane & ZIF-4 & SF 1.71 ethane/ethylene & NS & 293 & $\begin{array}{c}\text { up to } \\
12\end{array}$ & [231] \\
\hline ethylene/ethane & Ag-X & S 15.9 ethylene & P $9.04^{1}$ & 303 & NS & [232] \\
\hline ethylene/ethane & 6FDA-DAM:DABA & SF 9 ethylene/ethane & P 90 ethylene (barrer) & 308 & 3.44 & [233] \\
\hline ethylene/ethane & ZIF-7 & NS & NS & NS & 0 & {$[77]$} \\
\hline ethylene/ethane & ZIF-8 & S 2.8 ethylene & P 1.5 ethylene $^{1}$ & 298 & 1 & [78] \\
\hline ethylene/ethane & Cu3BTC2 & SF 7.1 ethylene/ethane & $\mathrm{P} 17^{1}$ & 423 & 5 & [234] \\
\hline ethylene/ethane & Cu3BTC2 & SF 7.1 ethylene/ethane & $\mathrm{P} 17^{1}$ & 423 & 5 & [234] \\
\hline ethylene/ethane & IRMOF-8 & S 1.43 Ethane/Ethylene & NS & 318 & 8 & [235] \\
\hline ethylene/ethane & MIL-101 & SF 16.5 ethylene/ethane & NS & 303 & 1 & [236] \\
\hline ethylene/ethane & MIL-100 & 111 ethylene/ethane & NS & 298 & 0.01 & [225] \\
\hline ethylene/ethane & M-MOF-74 & SF 10 ethylyne/ethane & NS & 318 & 1 & [237] \\
\hline ethylene/ethane & Mg2(dhtp) & S 1.4 ethylene/ethane & NS & 293 & 0.015 & [238] \\
\hline ethylene/ethane & Co2(dhtp) & S 1.7 ethylene/ethane & NS & 293 & 0.015 & [238] \\
\hline ethylene/ethane & ZIF-8 & S 0.48 ethylene/ethane & NS & 293 & 0.015 & [238] \\
\hline ethylene/ethane & $\mathrm{Fe} 2($ dobdc) & NS & NS & 318 & NS & [101] \\
\hline ethylene/ethane & CuBTC & NS & NS & $303 ; 373$ & $0.01-5$ & [239] \\
\hline ethylene/ethane & ZIF-71 & $\begin{array}{c}\text { SF } 1.84 \\
\text { propane/propylene }\end{array}$ & NS & 293 & 1 & [240] \\
\hline propylene/propane & Mg2(dhtp) & S 1.7 propylene/propane & NS & 293 & 0.015 & [238] \\
\hline propylene/propane & Co2(dhtp) & S 2.9 propylene/propane & NS & 293 & 0.015 & [238] \\
\hline propylene/propane & ZIF-8 & S 0.7 propylene/propane & NS & 293 & 0.015 & [238] \\
\hline propylene/propane & Fe2(dobdc) & NS & NS & 318 & NS & [101] \\
\hline propylene/propane & CuBTC & NS & NS & $303 ; 373$ & $0.01-5$ & [239] \\
\hline propylene/propane & ZIF-8 & NS & NS & NS & 1 & [241] \\
\hline propylene/propane & $\begin{array}{c}\text { Basolite } ® C 300 \\
\text { (BASF) }\end{array}$ & NS & NS & $323-373$ & 5 & [79] \\
\hline propylene/propane & $\begin{array}{c}\text { 6FDA-Durene/ } \\
\text { DABAco-polyimides } \\
\text { ZIF-8 }\end{array}$ & $\begin{array}{c}\text { SF } 27.38 \\
\text { propylene/propane }\end{array}$ & NS & 308 & 10.13 & [242] \\
\hline propylene/propane & $\begin{array}{c}\text { NbOFFIVE-1-Ni } \\
\text { (KAUST-7) }\end{array}$ & NS & NS & 298 & 1 & [243] \\
\hline propylene/propane & ZIF-9 & SF 1.39 ethane/ethylene & NS & 293 & 1 & [240] \\
\hline propylene/propane & Zr-fum-fcu-MOF & NS & NS & 328 & NS & [80] \\
\hline propylene/propane & MIL-100 & 70 propylene/propane & NS & 298 & 0.01 & [225] \\
\hline
\end{tabular}

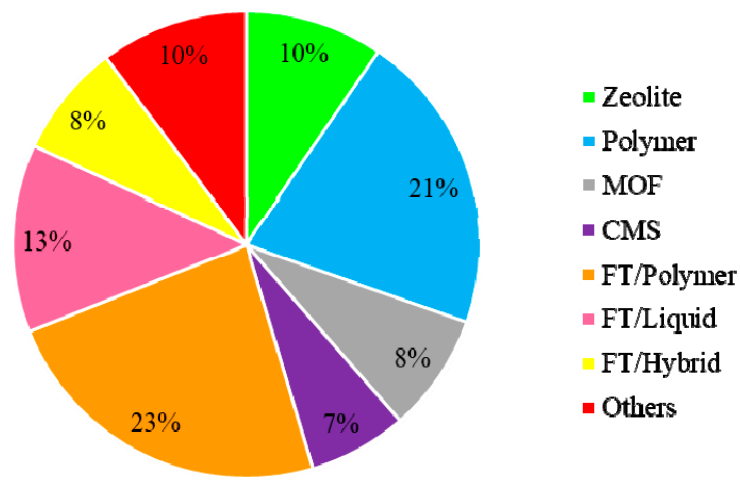

Figure 8. Distribution of membrane technologies used for separation of gaseous paraffin/olefin mixtures.

As also observed in the published papers, the considerations regarding the membranes type in the deposited patents, as observed in Figure 9, show that polymers and polymers combined to metal carriers represent around $60 \%$ of the used materials. Also, other types of membranes were 
observed. CMSs, MOFs and zeolites depict almost $25 \%$ of the read patents. Facilitated transport and solution-diffusion are the most separation mechanisms, nearly $80 \%$. Silver represents $82 \%$ of all the carriers used, however, gold and copper have been exploited [244]. As can be noticed, silver dominates the studies as also observed for the paper bibliometric analysis.

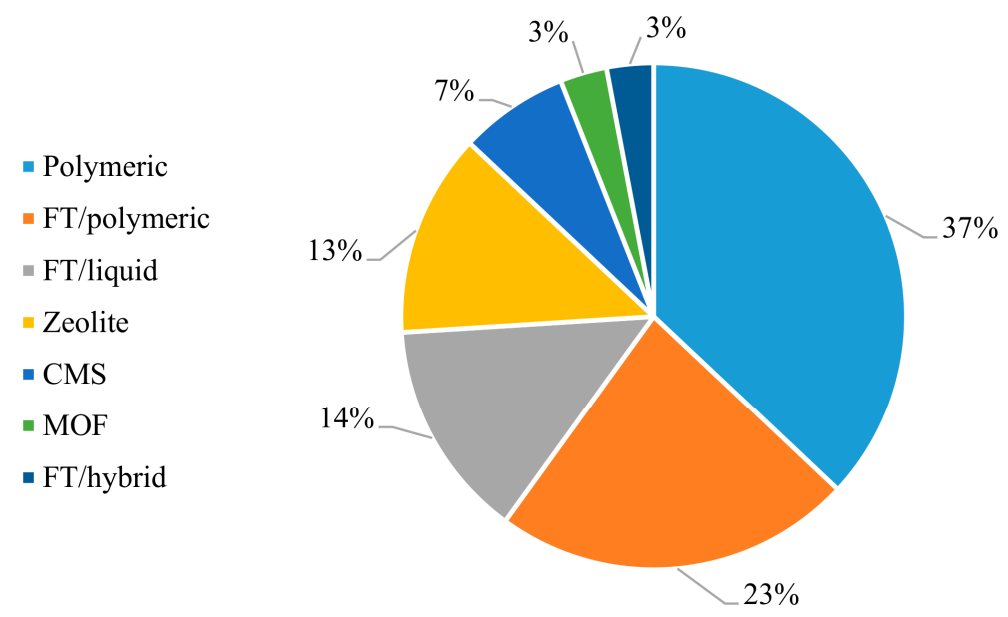

Figure 9. Types of membranes for paraffin/olefin separations.

However, zeolites [245], carbon molecular sieve [246] and metal-organic framework [247] membranes began to appear as interesting alternatives to overcome the separation limit traditionally observed for polymeric membranes.

The analyses of patents that regard olefin/paraffin separations apparently indicate that the development of new stable, highly permeable and highly selective facilitated transport membranes constitutes a critical issue for the future success of the technology, as commercial players are still searching for improvements that will make FTMs more attractive and viable [248-253]. It is also important to highlight that most feed streams reported in published patents contain simple mixtures of pure gases, so that the membrane performances have rarely been validated with real gas mixtures, meaning that deactivation of FTMs have probably been underestimated in most documents. Finally, actual industrial applications have not been properly documented in available patents, illustrating the scalability problems of the technology. Despite that, given the possible benefits obtained by overcoming the disadvantages usually associated with the conventional gas separation methods, it is certain that additional studies and investments will be performed to make the technology more viable and ready for commercial application.

\subsection{The Carrier Agents}

Figure 10 presents the relative frequency of carriers reported in the literature. As one can observe, silver concentrates almost $90 \%$ of the papers published in the field of FTM. It must be noted that neutral Ag-nanoparticles have also been used as carriers in FTM processes. As reported in some documents, neutral Ag-nanoparticles are chemically stable, present excellent long-term performances and can lead to high selectivities and permeabilities [249]. Particularly, Campos et al (2018) [59] presented a critical analysis regarding the current state of development, the possible applications and the unstable nature of FTM carriers, proposing alternatives to overcome the problems that hamper the growth of the technology. These authors called attention to the fact that poisoning sources and membrane deactivation factors had not been properly analyzed in the published material. 


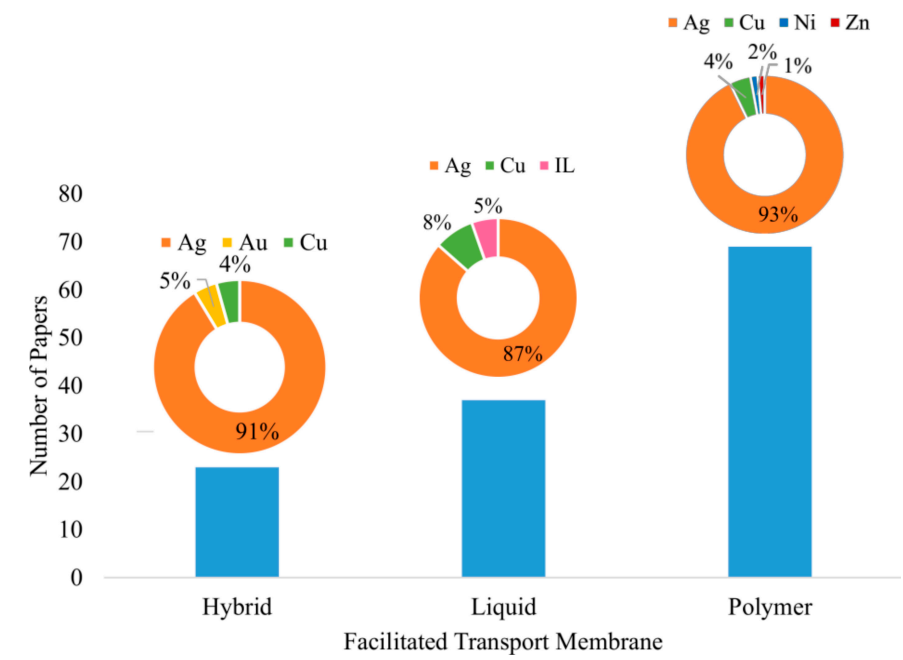

Figure 10. Distribution of carriers used for separation of gaseous paraffin/olefin mixtures in FTM processes.

\subsection{The Poisonous Agents and the Lifetime}

It is important to emphasize that very few works analyzed the influence of contaminants [59] and the long-term performances of the separation modules [254], as shown in Figure 11. As a matter of fact, the presence of contaminants can exert strong negative effects on the performances of commercial scale membrane separation processes [59], which indicates that published papers regard the characterization of ideal separations and neglect the complexity of gaseous mixtures processed industrially. The poisonous agents identified in this work were acetylene and sulfur $[125,207]$, reduction [90] and silver deposition [158], ketone [255], membrane dehydration [161], olefins and hydrogen [207].

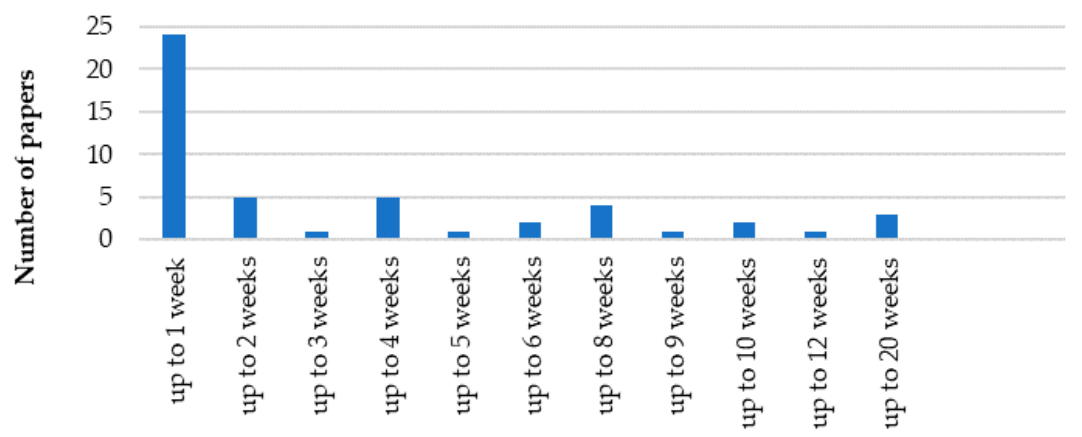

Figure 11. Lifetimes of membranes used for separation of gaseous paraffin/olefin mixtures in FTM processes.

Table 13 and Figure 11 present the membrane lifetimes reported in several papers, showing very short lifetimes in most cases. Although it is true that most published material regard lab-scale operations, this certainly is an indication of frequent process interruptions, changes of membrane modules and regeneration of separation units, rendering the process operation less efficient and more expensive [17]. Among the analyzed studies, the silver based CAF (amorphous fluoropolymer) membrane developed by Compact Membrane Systems (CMS) seemed to present superior performances in terms of operation lifetimes and selectivities for propylene/propane separations (although, according to the authors, similar results could be obtained with ethylene/ethane separations) [207]. This study reported selectivities of 50 and permeabilities of 200 GPU of propylene over a period of $300 \mathrm{~d}$ in lab-scale operations. Besides, the membrane was shown to be stable in presence of hydrogen sulfide, acetylene and hydrogen, although membrane humidification was needed to improve the process performance and stability. 
Table 13. Lifetimes of membranes used for separation of gaseous paraffin/olefin mixtures in FTM processes.

\begin{tabular}{|c|c|c|c|c|c|c|}
\hline Separated Gases & Name of the Material & Carrier & Temp (K) & Pressure (bar) & Lifetime & Ref. \\
\hline 1-butene/n-butane & ILMs in PVDF substrates & $\mathrm{Ag}^{+}$ & NS & 0.14 & at least $600 \mathrm{~h}$ & [256] \\
\hline ethylene/ethane & Fluoropore FP-010/AgNO & $\mathrm{Ag}^{+}$ & 298 & 1.01 & at least $100 \mathrm{~h}$ & [90] \\
\hline ethylene/ethane & EPDM-SPEEK & $\mathrm{Ag}^{+}$ & 298 & 3 & at least $1680 \mathrm{~h}$ & [131] \\
\hline ethylene/ethane & $\mathrm{ZnCl}_{2} /[\mathrm{BMIM}][\mathrm{Cl}]$ & $\mathrm{Cu}$ & 298 & 1.1 & $150 \mathrm{~h}$ & [257] \\
\hline ethylene/ethane & $\mathrm{AgBF}_{4} / \mathrm{PEO}$ & $\mathrm{Ag}^{+}$ & 296 & 1.72 & at least $16 \mathrm{~h}$ & [139] \\
\hline ethylene/ethane & $\mathrm{AgNO}_{3} /$ polyethersulfone & $\mathrm{Ag}^{+}$ & 298 & 0.09 & $1440 \mathrm{~h}$ & [141] \\
\hline ethylene/ethane & $\mathrm{PA} 12-\mathrm{PTMO} / \mathrm{AgBF}_{4}$ & $\mathrm{Ag}^{+}$ & 295 & 3.44 & $72 \mathrm{~h}$ & [142] \\
\hline ethylene/ethane & EPDM & $\mathrm{Ag}^{+}$ & 298 & 3 & over $3360 \mathrm{~h}$ & [136] \\
\hline ethylene/ethane & $\mathrm{AgNO}_{3} /$ polyethersulfone & $\mathrm{Ag}^{+}$ & 298 & 2 & $504 \mathrm{~h}$ & [144] \\
\hline ethylene/ethane & $\mathrm{SiO}_{2}$ Poly(sodium acrylate) $\mathrm{Ag}^{+}$ & $\mathrm{Ag}^{+}$ & 373 & 2 & at least $5 \mathrm{~h}$ & [147] \\
\hline ethylene/ethane & Pebax®2533/AgBF 4 & $\mathrm{Ag}^{+}$ & 296 & 3.44 & 7 days & [115] \\
\hline ethylene/ethane & $\mathrm{Psf} / \mathrm{AgNO}_{3}$ & $\mathrm{Ag}^{+}$ & NS & 1 & $1440 \mathrm{~h}$ & [148] \\
\hline ethylene/ethane & $\mathrm{PEO}-\mathrm{AgBF}_{4}$ & $\mathrm{Ag}^{+}$ & 296 & 7.9 & at least $20 \mathrm{~h}$ & [151] \\
\hline i-butene/i-butane & $\left(\right.$ PTMSP-g-AA-Ag $\left.{ }^{+}\right)$ & $\mathrm{Ag}^{+}$ & 298 & NS & at least $1008 \mathrm{~h}$ & [258] \\
\hline isoprene/n-pentane & SPEEK-AgNO & $\mathrm{Ag}^{+}$ & 333 & 101.325 & $100 \mathrm{~h}$ & [259] \\
\hline pentene/pentane & Select & $\mathrm{Ag}^{+}$ & 298 & 1.013 & $48 \mathrm{~h}$ & [260] \\
\hline propylene/propane & $\mathrm{POZ} / \mathrm{AgNO}_{3} / \mathrm{SiO}_{2}$ & $\mathrm{Ag}^{+}$ & 293 & 2.75 & $160 \mathrm{~h}$ & [154] \\
\hline propylene/propane & $\mathrm{PVP} / \mathrm{Nano} \mathrm{Au}$ & $\mathrm{Au}$ & 298 & 1.013 & 2 days & [96] \\
\hline propylene/propane & $\mathrm{POZ}$ & $\mathrm{Ag}^{+}$ & 293 & 2.75 & 14 days & [156] \\
\hline propylene/propane & PVDF-HFP/BMImBF ${ }_{4}^{-} \mathrm{Ag}^{+}$ & $\mathrm{Ag}^{+}$ & $293-323$ & $0.5-3$ & 10 days & [157] \\
\hline propylene/propane & $\mathrm{AgNO}_{3} / \mathrm{Al}_{2} \mathrm{O}_{3}$ & $\mathrm{Ag}^{+}$ & 298 & 1 & at least $4320 \mathrm{~h}$ & [158] \\
\hline propylene/propane & $\mathrm{TiO}_{2}-\mathrm{PEO}-\mathrm{AgBF}_{4}$ & $\mathrm{Ag}^{+}$ & 298 & 1 & less than $196 \mathrm{~h}$ & [160] \\
\hline propylene/propane & Permylene & $\mathrm{Ag}^{+}$ & 298 & 5.56 & over $1000 \mathrm{~h}$ & [161] \\
\hline propylene/propane & $\mathrm{POZ} / \mathrm{P} 154 \mathrm{AgNO}_{3} / \mathrm{BMIM}^{+} \mathrm{NO}_{3}{ }^{-}$ & $\mathrm{Ag}^{+}$ & NS & NS & $150 \mathrm{~h}$ & [163] \\
\hline propylene/propane & $\mathrm{TEG} / \mathrm{AgBF}_{4}$ & $\mathrm{Ag}^{+}$ & 293-298 & 1.013 & $1440-2160 \mathrm{~h}$ & [165] \\
\hline propylene/propane & $\mathrm{PVDF} / \mathrm{AgNO}_{3}$ & $\mathrm{Ag}^{+}$ & 298 & 1.2 & $2880 \mathrm{~h}$ & [167] \\
\hline propylene/propane & $\mathrm{BMIM}^{+} \mathrm{BF}_{4}^{-} / \mathrm{Ag}$ & $\mathrm{Ag}^{+}$ & NS & 2.75 & at least $100 \mathrm{~h}$ & [168] \\
\hline propylene/propane & $\mathrm{AgNO}_{3} / \mathrm{PVDF}$ & $\mathrm{Ag}^{+}$ & 298 & 1.2 & 3-4 weeks & [170] \\
\hline propylene/propane & $\mathrm{PVDF} / \mathrm{AgNO}_{3}$ & $\mathrm{Ag}^{+}$ & 298 & 1.2 & 3-4 weeks & [175] \\
\hline propylene/propane & $\mathrm{PVDF} / \mathrm{AgNO}_{3}$ & $\mathrm{Ag}^{+}$ & NS & NS & $2880 \mathrm{~h}$ & [118] \\
\hline propylene/propane & NMP & $\mathrm{Ag}^{+}$ & 293 & $1.2-2.2$ & $60 \mathrm{~h}$ & [180] \\
\hline propylene/propane & $\mathrm{Cu} / \mathrm{PVP}$ & $\mathrm{Cu}$ & 298 & 1.38 & $168 \mathrm{~h}$ & [184] \\
\hline propylene/propane & $\mathrm{AgBF}_{4}-\mathrm{PVP}$ & $\mathrm{Ag}^{+}$ & NS & NS & at least $100 \mathrm{~h}$ & [124] \\
\hline propylene/propane & POZ & $\mathrm{Ag}^{+}$ & 296 & 1.38 & $50 \mathrm{~h}$ & [186] \\
\hline propylene/propane & $\mathrm{AgBF}_{4}-\mathrm{PVP}$ & $\mathrm{Ag}^{+}$ & NS & NS & at least $100 \mathrm{~h}$ & [188] \\
\hline propylene/propane & $\mathrm{AgBF}_{4}-\mathrm{POZ}$ & $\mathrm{Ag}^{+}$ & NS & NS & at least $100 \mathrm{~h}$ & [188] \\
\hline propylene/propane & $\mathrm{PVP} / \mathrm{AgBF}_{4}$ & $\mathrm{Ag}^{+}$ & NS & 2.76 & $720 \mathrm{~h}$ & [190] \\
\hline propylene/propane & $\mathrm{PEP} / \mathrm{AgBF}_{4}$ & $\mathrm{Ag}^{+}$ & 293 & 2.758 & $150 \mathrm{~h}$ & [94] \\
\hline propylene/propane & $\mathrm{PDMS} \mathrm{AgBF}_{4}$ & $\mathrm{Ag}^{+}$ & NS & 1.38 & at least $5.8 \mathrm{~h}$ & [193] \\
\hline propylene/propane & PTFE & $\mathrm{Ag}^{+}$ & 298 & 1.2 & 2 months & [121] \\
\hline propylene/propane & poly(vinylalcohol)/ $/ \mathrm{AgBF}_{4} / \mathrm{Al}\left(\mathrm{NO}_{3}\right)_{3}$ & $\mathrm{Ag}^{+}$ & NS & 3 & $145 \mathrm{~h}$ & [98] \\
\hline propylene/propane & CAF (CMS) & $\mathrm{Ag}^{+}$ & 298 & 5.15 & over 9 months & [207] \\
\hline propylene/propane & PEO-AgBF & $\mathrm{Ag}^{+}$ & 296 & 7.9 & at least $20 \mathrm{~h}$ & [151] \\
\hline
\end{tabular}




\subsection{The Layouts and Operation Conditions}

Figure 12 shows the equipment layouts used to perform membrane separations in different publications. The commonest membrane layouts employed in the analyzed articles were flat sheets ( $52 \%$ of the total number of papers), although it is important to note that the layout was not specified in $29 \%$ of the papers. Given the fact that most of these papers conducted separation tests in lab-scale units, the number of flat sheets is probably larger than the shown value. Only $14 \%$ of the documents employed hollow fiber membranes, while just $1 \%$ of the papers reported the use of spiral wound membranes. These numbers reinforce the fact that the vast majority of the investigations made use of small lab-scale setups for characterization of membrane performances and did not analyze the performances of larger commercial scale units. Therefore, once more it can be observed that the published material suggests that the degree of technological maturity of these processes is small and that research is concentrated on development and characterization of membrane materials, not on the implementation of actual commercial separation equipment. Moreover, the use of soft operating conditions (mainly 1 bar of pressure and ambient temperature) in most published documents indicates the lab scale characterization, as reported Figures 13 and 14.

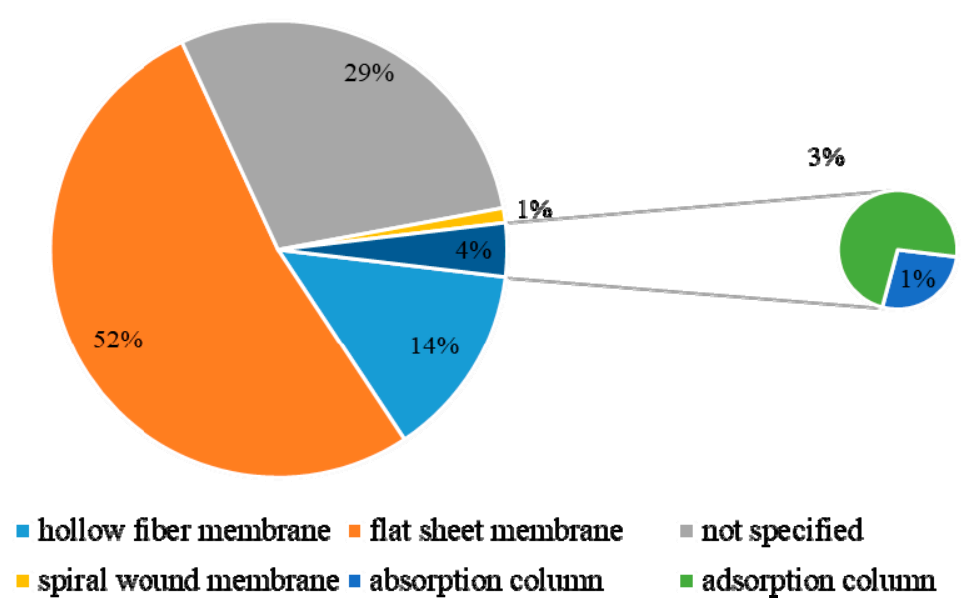

Figure 12. Distribution of layouts used to perform separations of gaseous paraffin/olefin mixtures.

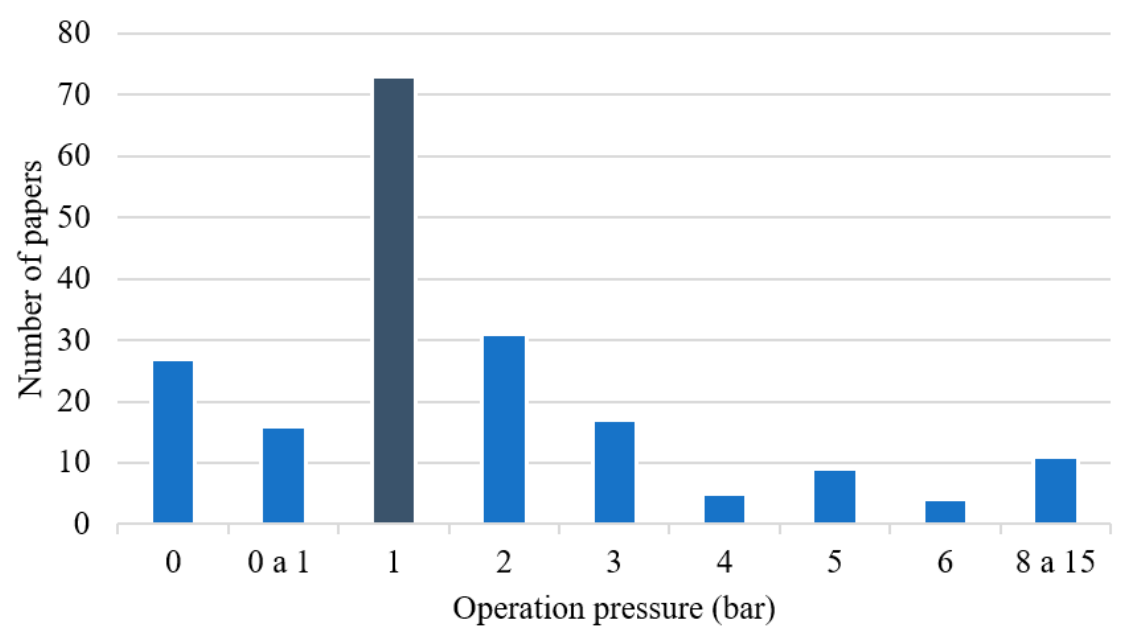

Figure 13. Pressures used to perform separations of gaseous paraffin/olefin mixtures. 


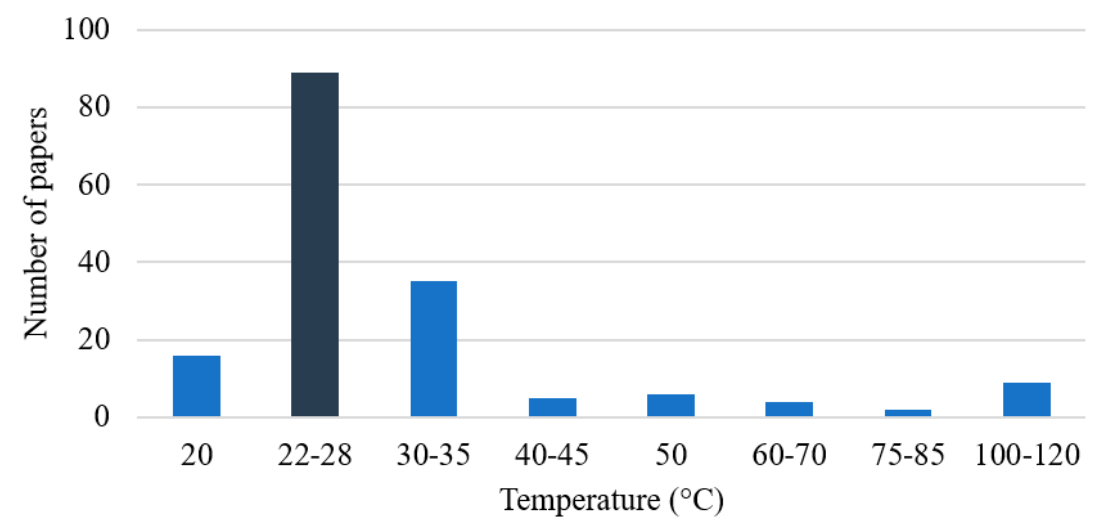

Figure 14. Temperatures used to perform separations of gaseous paraffin/olefin mixtures.

\section{Conclusions}

The present study surveyed the research on paraffin/olefin separations using membranes during the 1960-2019 period. Relevant information related to annual publication distribution, journals, main countries and institutions was analyzed. The first document analyzed was published in 1961 and the researches until 2010 were very limited. The journal that published more documents was Journal of Membrane Science, followed by Industrial and Engineering Chemistry Research and Separation and Purification Technology, publishing together almost $50 \%$ of the analyzed papers. The USA was the most productive country followed by South Korea and Iran. The second position attained by South Korea must be highlighted, since the Korea Institute of Science and Technology ranked in first among the top five most productive institutions.

The use of membranes for paraffin/olefin separation has not been successful for commercial applications yet. Zeolites, CMS and MOFs are new types of materials that have been studied more deeply since 2010 in order to overcome stability, selectivity and permeability issues encountered in other types of membranes. However, studies are still in lab scale. Facilitated transport separation using Ag as carrier was clearly the most relevant application and much research effort has been devoted to this topic.

Ethylene/ethane separations have been investigated to less extension than propylene/propane separations. Nonetheless, the separation of a great diversity of mixtures of organic compounds has been proposed. Flat sheet membranes dominate most studies and operating conditions are typical of lab-scale operations, suggesting that the use of membranes for paraffin/olefin separations still constitutes an immature field that has not been established industrially. This lack of technological maturity can be supported by many aspects. First, despite the fact that this issue has been discussed since the 1960s, the number of papers related to this theme is relatively small and the rate of publications in this field has not increased much since then. Besides, the types of materials reported for manufacture of the membranes is huge, indicating that consensus regarding the materials that are best suited for the analyzed applications has yet to be reached. Additionally, most membranes used for paraffin/olefin separations present short lifetimes, usually shorter than 2 weeks. This scenario possibly explains why reported membrane areas, flows, temperatures and feed pressures were obtained in laboratory scale and using ideal gas mixtures.

In spite of the current scenario, one cannot deny the many significant improvements achieved in this field. For instance, development of porous membranes with well-defined pore size distributions, including CMSs, zeolites, PIMs and MOFs, can overcome the inherent separation limits of dense polymer membranes. Also, some studies showed that conventional membranes based on solution-diffusion mechanisms are inefficient to produce high-purity olefin streams and that facilitated transport membranes (particularly the ones that contain silver-based carriers) constitute promising candidates to achieve high selectivity and permeability. Finally, based in the bibliometric analysis presented in the present study, it seems plausible to affirm that membranes that include the use of silver as a carrier 
(facilitated transport membranes and MOFs) seem to constitute the most promising technologies so far. However, these membranes are very sensitive and may be deactivated in the presence of $\mathrm{H}_{2} \mathrm{~S}$, sulfur, acetylene, olefins and by the reduction of the metal used as the olefin carrier, which demands additional and detailed studies about the effects of poisoning and membrane operation on the performance and stability of membrane separation units.

Supplementary Materials: The file of Supplementary Materials [261-328] are available online at http://www. mdpi.com/2077-0375/9/12/157/s1, Table S1. Distribution of membranes used for gas separations involving paraffins and/or olefins (background rated category), excluding the separation between paraffins and olefins; Table S2. Distribution of membranes and conditions used for paraffin/olefin separations; Table S3. Papers analyzed in the bibliometric study.

Author Contributions: Conceptualization, D.M.V.d.M., L.d.S.D., D.W., F.W., M.C.S., N.J. and J.C.P.; methodology, D.M.V.d.M., L.d.S.D., D.W., F.W., M.C.S., N.J. and J.C.P.; formal analysis, D.M.V.d.M., L.d.S.D., D.W. and J.C.P.; investigation, D.M.V.d.M., L.d.S.D., D.W., F.W., M.C.S., N.J., N.A. and J.C.P.; resources, J.C.P.; data curation, D.M.V.d.M., L.d.S.D., D.W., F.W. and N.A.; writing-original draft preparation, D.M.V.d.M., L.d.S.D. and D.W.; writing-review and editing, D.M.V.d.M., L.d.S.D., J.C.P. and D.W.; visualization, D.M.V.d.M., L.d.S.D., D.W. and J.C.P.; supervision, J.C.P.; project administration, J.C.P., D.M.V.d.M. and L.d.S.D.; funding acquisition, B.S.A.

Funding: This research was supported by the Braskem S.A.; Conselho Nacional de Desenvolvimento Científico e Tecnológico (CNPq) and Coordenação de Aperfeiçoamento de Pessoal de Nível Superior (CAPES).

Conflicts of Interest: The authors declare no conflict of interest.

\section{References}

1. Eldridge, R.B. Olefin/paraffin separation technology: a review. Ind. Eng. Chem. Res. 1993, 32, $2208-2212$. [CrossRef]

2. Rungta, M.; Zhang, C.; Koros, W.J.; Xu, L. Membrane-based ethylene/ethane separation: The upper bound and beyond. AIChE J. 2013, 59, 3475-3489. [CrossRef]

3. Kenarsari, S.D.; Yang, D.; Jiang, G.; Zhang, S.; Wang, J.; Russell, A.G.; Wei, Q.; Fan, M. Review of recent advances in carbon dioxide separation and capture. RSC Adv. 2013, 3. [CrossRef]

4. Ferraz, H.C.; Duarte, L.T.; Di Luccio, M.; Alves, T.L.M.; Habert, A.C.; Borges, C.P. Recent achievements in facilitated transport membranes for separation processes. Braz. J. Chem. Eng. 2007, 4, 101-118. [CrossRef]

5. Bernardo, P.; Drioli, E.; Golemme, G. Membrane Gas Separation: A Review/State of the Art. Ind. Eng. Chem. Res. 2009, 48, 4638-4663. [CrossRef]

6. Baker, R.W.; Low, B.T. Gas separation membrane materials: A perspective. Macromolecules 2014, 47, 6999-7013. [CrossRef]

7. Godini, H.R.; Kim, M.; Görke, O.; Khadivi, M.; Schomäcker, R.; Repke, J.U. Membrane Engineering for the Treatment of Gases: Gas-separation Issues Combined with Membrane Reactors; Royal Society of Chemistry: London, UK, 2011; ISBN 978-1849732390.

8. Hou, J.; Liu, P.; Jiang, M.; Yu, L.; Li, L.; Tang, Z. Olefin/paraffin separation through membranes: from mechanisms to critical materials. J. Mater. Chem. A 2019, 7, 23489-23511. [CrossRef]

9. Norwahyu, J.; Lau, K.K.; Yeong, Y.F.; Shariff, A.M. Bulk $\mathrm{CO}_{2} / \mathrm{CH}_{4}$ Separation for Offshore Operating Conditions using Membrane Process. Sains Malaysiana 2016, 45, 1707-1714.

10. Ismail, N.M.; Ismail, A.F.; Mustaffa, A. Characterization of polyethersulfone/cloisite 15A mixed matrix membrane for $\mathrm{CO}_{2} / \mathrm{CH}_{4}$ separation. J. Teknol. (Sci. Eng.) 2014, 69, 83-87. [CrossRef]

11. Doğu, M.; Ercan, N. High performance cyclic olefin copolymer (COC) membranes prepared with melt processing method and using of surface modified graphitic nano-sheets for $\mathrm{H}_{2} / \mathrm{CH}_{4}$ and $\mathrm{H}_{2} / \mathrm{CO}_{2}$ separation. Chem. Eng. Res. Des. 2016, 109, 455-463. [CrossRef]

12. Wiheeb, A.D.; Kim, J.; Othman, M.R. Highly Perm-Selective Micro-Porous Hydrotalcite-Silica Membrane for Improved Carbon Dioxide-Methane Separation. Sep. Sci. Technol. 2015, 50, 1701-1708. [CrossRef]

13. Han, Y.J.; Ko, K.J.; Choi, H.K.; Moon, J.H.; Lee, C.H. Kinetic effects of methane on binary mixture separation on methyltriethoxysilane templated silica membranes. Sep. Purif. Technol. 2017, 182, 151-159. [CrossRef]

14. Khoshkharam, A.; Ghayyem, M.A.; Behbahani, R.M. Laboratory investigation of carbon dioxide separation from methane using a PES/Pebax 1657 composite membrane. Pet. Sci. Technol. 2017, 35, 471-478. [CrossRef]

15. Shamsabadi, A.A.; Kargari, A.; Farshadpour, F.; Laki, S. Mathematical Modeling of $\mathrm{CO}_{2} / \mathrm{CH}_{4}$ Separation by Hollow Fiber Membrane Module Using Finite Difference Method. J. Membr. Sep. Technol. 2012, 1, 19-29. 
16. Chew, T.L.; Ahmad, A.L.; Bhatia, S. Microwave heating-synthesized zeolite membrane for $\mathrm{CO}_{2} / \mathrm{CH}_{4}$ separation. Desalin. Water Treat. 2012, 47, 139-149. [CrossRef]

17. Chung, T.S.; Jiang, L.Y.; Li, Y.; Kulprathipanja, S. Mixed matrix membranes (MMMs) comprising organic polymers with dispersed inorganic fillers for gas separation. Prog. Polym. Sci. 2007, 32, 483-507. [CrossRef]

18. Hamrahi, Z.; Kargari, A. Modification of polycarbonate membrane by polyethylene glycol for $\mathrm{CO}_{2} / \mathrm{CH}_{4}$ separation. Sep. Sci. Technol. 2017, 52, 544-556. [CrossRef]

19. Askari, M.; Yang, T.; Chung, T.S. Natural gas purification and olefin/paraffin separation using cross-linkable dual-layer hollow fiber membranes comprising B-Cyclodextrin. J. Membr. Sci. 2012, 423, 392-403. [CrossRef]

20. Isanejad, M.; Azizi, N.; Mohammadi, T. Pebax membrane for $\mathrm{CO}_{2} / \mathrm{CH}_{4}$ separation: Effects of various solvents on morphology and performance. J. Appl. Polym. Sci. 2017, 134, 1-9. [CrossRef]

21. Zou, X.; Zhang, F.; Thomas, S.; Zhu, G.; Valtchev, V.; Mintova, S. $\mathrm{Co}_{3}(\mathrm{HCOO})_{6}$ Microporous Metal-Organic Framework Membrane for Separation of $\mathrm{CO}_{2} / \mathrm{CH}_{4}$ Mixtures. Chem. - A Eur. J. 2011, 17, 12076-12083. [CrossRef]

22. Shahid, S.; Nijmeijer, K. Performance and plasticization behavior of polymer-MOF membranes for gas separation at elevated pressures. J. Membr. Sci. 2014, 470, 166-177. [CrossRef]

23. Saedi, S.; Seidi, F.; Moradi, F.; Xiang, X. Preparation and characterization of an amino-cellulose (AC) derivative for development of thin-film composite membrane for $\mathrm{CO}_{2} / \mathrm{CH}_{4}$ separation. Starch/Staerke 2016, 68, 651-661. [CrossRef]

24. Zheng, Y.; Hu, N.; Wang, H.; Bu, N.; Zhang, F.; Zhou, R. Preparation of steam-stable high-silica CHA (SSZ-13) membranes for $\mathrm{CO}_{2} / \mathrm{CH}_{4}$ and $\mathrm{C} 2 \mathrm{H} 4 / \mathrm{C} 2 \mathrm{H} 6$ separation. J. Membr. Sci. 2015, 475, 303-310. [CrossRef]

25. Han, Y.J.; Kang, J.H.; Kim, H.E.; Moon, J.H.; Cho, C.H.; Lee, C.H. Separation of Carbon Dioxide and Methane Mixture by an Adsorbent/Membrane Hybrid System Using Zeolite 5A Pellets and FAU-Zeolite Membrane. Ind. Eng. Chem. Res. 2017, 56, 2582-2591. [CrossRef]

26. Atchariyawut, S.; Jiraratananon, R.; Wang, R. Separation of $\mathrm{CO}_{2}$ from $\mathrm{CH}_{4}$ by using gas-liquid membrane contacting process. J. Membr. Sci. 2007, 304, 163-172. [CrossRef]

27. Ismail, N.; Salleh, W.; Sazali, N.; Ismail, A. The Effect of Polymer Composition on $\mathrm{CO}_{2} / \mathrm{CH}_{4}$ Separation of Supported Carbon Membrane. Chem. Eng. Trans. 2015, 45, 1465-1470.

28. Lai, L.S.; Yeong, Y.F.; Lau, K.K.; Shariff, A.M. Single and Binary $\mathrm{CO}_{2} / \mathrm{CH}_{4}$ Separation of a Zeolitic Imidazolate Framework-8 Membrane. Chem. Eng. Technol. 2017, 40, 1031-1042. [CrossRef]

29. Chultheera, P.; Rirksomboon, T.; Kulprathipanja, S.; Liu, C.; Chinsirikul, W.; Kerddonfag, N. Solid-Liquid-Polymer Mixed Matrix Membrane Using Liquid Additive Adsorbed on Activated Carbon Dispersed in Polymeric Membrane for $\mathrm{CO}_{2} / \mathrm{CH}_{4}$ Separation. World Acad. Sci. Eng. Technol. Int. J. Chem. Mol. Nucl. Mater. Metall. Eng. 2017, 11, 425-428.

30. Himeno, S.; Tomita, T.; Suzuki, K.; Nakayama, K.; Yajima, K.; Yoshida, S. Synthesis and Permeation Properties of a DDR-Type Zeolite Membrane for Separation of $\mathrm{CO}_{2} / \mathrm{CH}_{4}$ Gaseous Mixtures. Ind. Eng. Chem. Res. 2007, 46, 6989-6997. [CrossRef]

31. Khoshkam, M.; Sadeghi, M.; Chenar, M.P.; Namazifard, M.J. Synthesis of polyimide membrane for the separation of $\mathrm{CO}_{2} / \mathrm{CH}_{4}$ gases Chemical Engineering Department. In Proceedings of the Polymer Processing Society Asia/Australia Regional Meeting, Mashhad, Iran, 15-17 November 2011; pp. 15-18.

32. Adewole, J.K.; Ahmad, A.L.; Ismail, S.; Leo, C.P.; Sultan, A.S. Comparative studies on the effects of casting solvent on physico-chemical and gas transport properties of dense polysulfone membrane used for $\mathrm{CO}_{2} / \mathrm{CH}_{4}$ separation. J. Appl. Polym. Sci. 2015, 132,1-10. [CrossRef]

33. Kim, S.; Ko, D.; Row, S.; Kim, J. Techno-economic evaluation of hybrid systems of pressure swing adsorption and membrane processes for coalbed methane separation. Chem. Eng. Res. Des. 2016, 115, 230-240. [CrossRef]

34. Saedi, S.; Madaeni, S.S.; Hassanzadeh, K.; Shamsabadi, A.A.; Laki, S. The effect of polyurethane on the structure and performance of PES membrane for separation of carbon dioxide from methane. J. Ind. Eng. Chem. 2014, 20, 1916-1929. [CrossRef]

35. Saedi, S.; Madaeni, S.S.; Arabi Shamsabadi, A.; Mottaghi, F. The effect of surfactants on the structure and performance of PES membrane for separation of carbon dioxide from methane. Sep. Purif. Technol. 2012, 99, 104-119. [CrossRef]

36. Zahri, K.; Goh, P.S.; Ismail, A.F. The incorporation of graphene oxide into polysulfone mixed matrix membrane for $\mathrm{CO}_{2} / \mathrm{CH}_{4}$ separation. IOP Conf. Ser. Earth Environ. Sci. 2016, 36, 012007. [CrossRef] 
37. Van Kemenade, H.P.; van Benthum, R.J.; Brouwers, J.J.H. Upgrading Carbon Dioxide/Methane Mixtures by using a Hybrid Membrane-Condensed Rotational Separation Process. Energy Technol. 2014, 2, 874-876. [CrossRef]

38. Lai, L.S.; Yeong, Y.F.; Keong Lau, K.; Azmi, M.S. Zeolitic Imidazolate Frameworks (ZIF): A Potential Membrane for $\mathrm{CO}_{2} / \mathrm{CH}_{4}$ Separation. Sep. Sci. Technol. 2014, 49, 1490-1508. [CrossRef]

39. Yeo, Z.Y.; Chai, S.P.; Zhu, P.W.; Mohamed, A.R. Development of a hybrid membrane through coupling of high selectivity zeolite T on ZIF-8 intermediate layer and its performance in carbon dioxide and methane gas separation. Microporous Mesoporous Mater. 2014, 196, 79-88. [CrossRef]

40. Chen, D.L.; Shang, H.; Zhu, W.; Krishna, R. Reprint of: Transient breakthroughs of $\mathrm{CO}_{2} / \mathrm{CH}_{4}$ and $\mathrm{C}_{3} \mathrm{H}_{6} / \mathrm{C}_{3} \mathrm{H}_{8}$ mixtures in fixed beds packed with Ni-MOF-74. Chem. Eng. Sci. 2015, 124, 109-117. [CrossRef]

41. Mohshim, D.F.; Mukhtar, H.; Man, Z. Composite blending of ionic liquid-poly(ether sulfone) polymeric membranes: Green materials with potential for carbon dioxide/methane separation. J. Appl. Polym. Sci. 2016, 133, 1-8. [CrossRef]

42. Suleman, M.S.; Lau, K.K.; Yeong, Y.F. Development and performance evaluation of Polydimethyl siloxane/Polysulfone (PDMS/PSF) composite membrane for $\mathrm{CO}_{2} / \mathrm{CH}_{4}$ separation. IOP Conf. Ser. Earth Environ. Sci. 2016, 36, 012014. [CrossRef]

43. Gamali, P.A.; Kazemi, A.; Zadmard, R.; Anjareghi, M.J.; Rezakhani, A.; Rahighi, R.; Madani, M. Distinguished discriminatory separation of $\mathrm{CO}_{2}$ from its methane-containing gas mixture via PEBAX mixed matrix membrane. Chinese J. Chem. Eng. 2018, 26, 137-143. [CrossRef]

44. Hasan, R.; Scholes, C.A.; Stevens, G.W.; Kentish, S.E. Effect of Hydrocarbons on the separation of carbon dioxide from methane through a polyimide gas separation membrane. Ind. Eng. Chem. Res. 2009, 48, 5415-5419. [CrossRef]

45. Deng, L.; Hägg, M.-B. Fabrication and Evaluation of a Blend Facilitated Transport Membrane for $\mathrm{CO}_{2} / \mathrm{CH}_{4}$ Separation. Ind. Eng. Chem. Res. 2015, 54, 11139-11150. [CrossRef]

46. Mohamad, M.B.; Fong, Y.Y.; Shariff, A. Gas Separation of Carbon Dioxide from Methane Using Polysulfone Membrane Incorporated with Zeolite-T. Procedia Eng. 2016, 148, 621-629. [CrossRef]

47. Zhao, H.; Ding, X.; Yang, P.; Li, L.; Li, X.; Zhang, Y. A novel multi-armed and star-like poly(ethylene oxide) membrane for $\mathrm{CO}_{2}$ separation. J. Membr. Sci. 2015, 489, 258-263. [CrossRef]

48. Erdni-Goryaev, E.M.; Alent'ev, A.Y.; Belov, N.A.; Ponkratov, D.O.; Shaplov, A.S.; Lozinskaya, E.I.; Vygodskii, Y.S. Gas separation characteristics of new membrane materials based on poly(ethylene glycol)-crosslinked polymers and ionic liquids. Pet. Chem. 2012, 52, 494-498. [CrossRef]

49. Rouleau, L.; Pirngruber, G.; Guillou, F.; Barrère-Tricca, C.; Omegna, A.; Valtchev, V.; Pera-Titus, M.; Miachon, S.; Dalmon, J.A. Nanocomposite MFI-alumina and FAU-alumina Membranes: Synthesis, Characterization and Application to Paraffin Separation and $\mathrm{CO}_{2}$ Capture. Oil Gas Sci. Technol. - Rev. l'IFP 2009, 64, 745-758. [CrossRef]

50. Ding, X.; Hua, M.M.; Zhao, H.; Yang, P.; Chen, X.; Xin, Q.; Zhang, Y. Poly (ethylene oxide) composite membrane synthesized by UV-initiated free radical photopolymerization for $\mathrm{CO}_{2}$ separation. J. Membr. Sci. 2017, 531, 129-137. [CrossRef]

51. Zhao, D.; Ren, J.; Li, H.; Hua, K.; Deng, M. Poly(amide-6-b-ethylene oxide)/SAPO-34 mixed matrix membrane for $\mathrm{CO}_{2}$ separation. J. Energy Chem. 2014, 23, 227-234. [CrossRef]

52. Zhang, C.; Wu, Y.; Zhang, Y.; Bai, Y.; Gu, J.; Sun, Y. Poly(ether-b-amide)/ethylene glycol monophenyl ether gel membrane with superior $\mathrm{CO}_{2} / \mathrm{N} 2$ separation performance fabricated by thermally induced phase separation method. J. Membr. Sci. 2016, 508, 136-145. [CrossRef]

53. Takht Ravanchi, M.; Kaghazchi, T.; Kargari, A. Application of membrane separation processes in petrochemical industry: a review. Desalination 2009, 235, 199-244. [CrossRef]

54. Park, H.B.; Kamcev, J.; Robeson, L.M.; Elimelech, M.; Freeman, B.D. Maximizing the right stuff: The trade-off between membrane permeability and selectivity. Science 2017, 356, eaab0530. [CrossRef] [PubMed]

55. Robeson, L.M. Correlation of separation factor versus permeability for polymeric membranes. J. Membr. Sci. 1991, 62, 165-185. [CrossRef]

56. Robeson, L.M. The upper bound revisited. J. Membr. Sci. 2008, 320, 390-400. [CrossRef]

57. Freeman, B.D. Basis of permeability/selectivity tradeoff relations in polymeric gas separation membranes. Macromolecules 1999, 32, 375-380. [CrossRef] 
58. Apel, P.Y.; Bobreshova, O.V.; Volkov, A.V.; Volkov, V.V.; Nikonenko, V.V.; Stenina, I.A.; Filippov, A.N.; Yampolskii, Y.P.; Yaroslavtsev, A.B. Prospects of Membrane Science Development. Membr. Membr. Technol. 2019, 1, 45-63. [CrossRef]

59. Campos, A.C.C.; Dos Reis, R.A.; Ortiz, A.; Gorri, D.; Ortiz, I. A Perspective of Solutions for Membrane Instabilities in Olefin/Paraffin Separations: A Review. Ind. Eng. Chem. Res. 2018, 57, 10071-10085. [CrossRef]

60. Hsiue, G.-H.; Yang, J.-S. Novel methods in separation of olefin/paraffin mixtures by functional polymeric membranes. J. Membr. Sci. 1993, 82, 117-128. [CrossRef]

61. Ma, X.; Liu, D. Zeolitic imidazolate framework membranes for light olefin/paraffin separation. Crystals 2019, 9, 14. [CrossRef]

62. Rungta, M.; Wenz, G.B.; Zhang, C.; Xu, L.; Qiu, W.; Adams, J.S.; Koros, W.J. Carbon molecular sieve structure development and membrane performance relationships. Carbon 2017, 115, 237-248. [CrossRef]

63. Ma, X.; Lin, Y.S.; Wei, X.; Kniep, J. Ultrathin carbon molecular sieve membrane for propylene/propane separation. AIChE J. 2016, 62, 491-499. [CrossRef]

64. Tanco, M.A.L.; Tanaka, D.A.P. Recent advances on carbon molecular sieve membranes (CMSMs) and reactors. Processes 2016, 4, 29. [CrossRef]

65. Faiz, R.; Li, K. Polymeric membranes for light olefin/paraffin separation. Desalination 2012, $287,82-97$. [CrossRef]

66. Al-Maythalony, B.A. Metal-organic framework based membranes for gas separation. In Advanced Nanomaterials for Membrane Synthesis and its Applications; Elsevier: Amsterdam, The Netherlands, 2019; pp. 203-226. ISBN 9780128145036.

67. Li, J.; Corma, A.; Yu, J. Synthesis of new zeolite structures. Chem. Soc. Rev. 2015, 44, 7112-7127. [CrossRef] [PubMed]

68. Wang, Y.; Peh, S.B.; Zhao, D. Alternatives to Cryogenic Distillation: Advanced Porous Materials in Adsorptive Light Olefin/Paraffin Separations. Small 2019. [CrossRef] [PubMed]

69. Kosinov, N.; Gascon, J.; Kapteijn, F.; Hensen, E.J.M. Recent developments in zeolite membranes for gas separation. J. Membr. Sci. 2016, 499, 65-79. [CrossRef]

70. Yaghi, O.M.; O'Keeffe, M.; Ockwig, N.W.; Chae, H.K.; Eddaoudi, M.; Kim, J. Reticular synthesis and the design of new materials. Nature 2003, 423, 705. [CrossRef]

71. Pabby, A.K.; Rizvi, S.S.H.; Sastre, A.M. Handbook of membrane separations: Chemical, pharmaceutical, food, and biotechnological applications, 2nd ed.; CRC Press: Boca Raton, FL, USA, 2015; ISBN 9781466555587.

72. Stern, E.W. Olefin-Paraffin Separation by Supported Cuprous Chloride. Ind. Eng. Chem. Process Des. Dev. 1962, 1, 281-284. [CrossRef]

73. Ho, W.S.W.; Doyle, G.; Savage, D.W.; Pruett, R.L. Olefin separations via complexation with cuprous diketonate. Ind. Eng. Chem. Res. 1988, 27, 334-337. [CrossRef]

74. Le, M.T. An assessment of the potential for the development of the shale gas industry in countries outside of North America. Heliyon 2018, 4, e00516. [CrossRef]

75. Hartmann, M.; Himsl, D.; Kunz, S.; Tangermann, O. Olefin/paraffin separation over the Metal Organic Framework material Cu3(BTC)2; Elsevier B.V.: Amsterdam, The Netherlands, 2008; Volume 174, ISBN 9780444532961.

76. Lamia, N.; Jorge, M.; Granato, M.A.; Almeida Paz, F.A.; Chevreau, H.; Rodrigues, A.E. Adsorption of propane, propylene and isobutane on a metal-organic framework: Molecular simulation and experiment. Chem. Eng. Sci. 2009, 64, 3246-3259. [CrossRef]

77. Gücüyener, C.; van den Bergh, J.; Gascon, J.; Kapteijn, F. Ethane/Ethene Separation Turned on Its Head: Selective Ethane Adsorption on the Metal-Organic Framework ZIF-7 through a Gate-Opening Mechanism. J. Am. Chem. Soc. 2010, 132, 17704-17706. [CrossRef] [PubMed]

78. Bux, H.; Chmelik, C.; Krishna, R.; Caro, J. Ethene/ethane separation by the MOF membrane ZIF-8: Molecular correlation of permeation, adsorption, diffusion. J. Membr. Sci. 2011, 369, 284-289. [CrossRef]

79. Ferreira, A.F.P.; Santos, J.C.; Plaza, M.G.; Lamia, N.; Loureiro, J.M.; Rodrigues, A.E. Suitability of Cu-BTC extrudates for propane-propylene separation by adsorption processes. Chem. Eng. J. 2011, 167, 1-12. [CrossRef]

80. Liu, Y.; Chen, Z.; Liu, G.; Belmabkhout, Y.; Adil, K.; Eddaoudi, M.; Koros, W. Conformation-Controlled Molecular Sieving Effects for Membrane-Based Propylene/Propane Separation. Adv. Mater. 2019. [CrossRef] 
81. Hayashi, J.; Mizuta, H.; Yamamoto, M.; Kusakabe, K.; Morooka, S.; Suh, S.-H. Separation of Ethane/Ethylene and Propane/Propylene Systems with a Carbonized BPDA-pp' ODA Polyimide Membrane. Ind. Eng. Chem. Res. 1996, 35, 4176-4181. [CrossRef]

82. Okamoto, K.; Kawamura, S.; Yoshino, M.; Kita, H.; Hirayama, Y.; Tanihara, N.; Kusuki, Y. Olefin/paraffin separation through carbonized membranes derived from an asymmetric polyimide hollow fiber membrane. Ind. Eng. Chem. Res. 1999, 38, 4424-4432. [CrossRef]

83. Menendez, I.; Fuertes, A.B. Aging of carbon membranes under different environments. Carbon 2001, 39, 733-740. [CrossRef]

84. Yoshino, M.; Nakamura, S.; Kita, H.; Okamoto, K.I.; Tanihara, N.; Kusuki, Y. Olefin/paraffin separation performance of carbonized membranes derived from an asymmetric hollow fiber membrane of 6FDA/BPDA-DDBT copolyimide. J. Membr. Sci. 2003, 215, 169-183. [CrossRef]

85. Curbelo, S.; Müller, E.A. Modelling of Ethane/Ethylene Separation Using Microporous Carbon. Adsorpt. Sci. Technol. 2005, 23, 855-866. [CrossRef]

86. Islam, M.N.; Zhou, W.; Honda, T.; Tanaka, K.; Kita, H.; Okamoto, K.I. Preparation and gas separation performance of flexible pyrolytic membranes by low-temperature pyrolysis of sulfonated polyimides. $J$. Membr. Sci. 2005, 261, 17-26. [CrossRef]

87. Karunaweera, C.; Musselman, I.H.; Balkus, K.J.; Ferraris, J.P. Fabrication and characterization of aging resistant carbon molecular sieve membranes for $\mathrm{C} 3$ separation using high molecular weight crosslinkable polyimide, 6FDA-DABA. J. Membr. Sci. 2019, 581, 430-438. [CrossRef]

88. Graham, T. On the absorption and dialytic separation of gases by colloid septa. J. Franklin Inst. 1867, 83, 39-41. [CrossRef]

89. Baker, R.W. Gas Separation. In Membrane Technology and Applications; Wiley: Newark, CA, USA, 2012; pp. 325-378. ISBN 978-0-470-74372-0.

90. Teramoto, M.; Matsuyama, H.; Yamashiro, T.; Okamoto, S. Separation of ethylene from ethane by a flowing liquid membrane using silver nitrate as a carrier. J. Membr. Sci. 1989, 45, 115-136. [CrossRef]

91. Zastrow, M. Why South Korea is the world's biggest investor in research. Nature 2016, 534. [CrossRef]

92. Kim, S.-J.; Lee, P.S.; Chang, J.-S.; Nam, S.-E.; Park, Y.-I. Preparation of carbon molecular sieve membranes on low-cost alumina hollow fibers for use in C3H6/C3H8 separation. Sep. Purif. Technol. 2018, 194, 443-450. [CrossRef]

93. Kim, J.; Kang, S.W.; Mun, S.H.; Kang, Y.S. Facile synthesis of copper nanoparticles by ionic liquids and its application to facilitated olefin transport membranes. Ind. Eng. Chem. Res. 2009, 48, 7437-7441. [CrossRef]

94. Kang, S.W.; Kim, J.H.; Oh, K.S.; Won, J.; Char, K.; Kim, H.S.; Kang, Y.S. Highly stabilized silver polymer electrolytes and their application to facilitated olefin transport membranes. J. Membr. Sci. 2004, 236, 163-169. [CrossRef]

95. Kang, S.W.; Lee, D.H.; Park, J.H.; Char, K.; Kim, J.H.; Won, J.; Kang, Y.S. Effect of the polarity of silver nanoparticles induced by ionic liquids on facilitated transport for the separation of propylene/propane mixtures. J. Membr. Sci. 2008, 322, 281-285. [CrossRef]

96. Kang, S.W.; Hong, J.; Park, J.H.; Mun, S.H.; Kim, J.H.; Cho, J.; Char, K.; Kang, Y.S. Nanocomposite membranes containing positively polarized gold nanoparticles for facilitated olefin transport. J. Membr. Sci. 2008, 321, 90-93. [CrossRef]

97. Kim, H.S.; Bae, J.Y.; Park, S.J.; Lee, H.; Bae, H.W.; Kang, S.O.; Lee, S.D.; Choi, D.K. Separation of olefin/paraffin mixtures using zwitterionic silver complexes as transport carriers. Chem. - A Eur. J. 2007, 13, 2655-2660. [CrossRef] [PubMed]

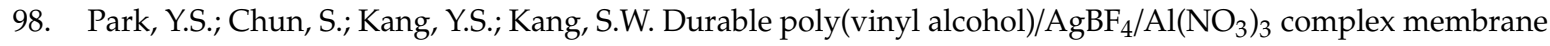
with high permeance for propylene/propane separation. Sep. Purif. Technol. 2017, 174, 39-43. [CrossRef]

99. Lee, J.H.; Kang, S.W.; Song, D.; Won, J.; Kang, Y.S. Facilitated olefin transport through room temperature ionic liquids for separation of olefin/paraffin mixtures. J. Membr. Sci. 2012, 423-424, 159-164. [CrossRef]

100. Jeong, S.; Kang, S.W. Effect of Ag2O nanoparticles on long-term stable polymer $/ \mathrm{AgBF}_{4} / \mathrm{Al}\left(\mathrm{NO}_{3}\right)_{3}$ complex membranes for olefin/paraffin separation. Chem. Eng. J. 2017, 327, 500-504. [CrossRef]

101. Bloch, E.D.; Queen, W.L.; Krishna, R.; Zadrozny, J.M.; Brown, C.M.; Long, J.R. Hydrocarbon separations in a metal-organic framework with open iron(II) coordination sites. Science 2012. [CrossRef]

102. Koros, W.J.; Mahajan, R. Pushing the limits on possibilities for large scale gas separation: Which strategies? J. Membr. Sci. 2001, 181, 141. [CrossRef] 
103. Lin, H.; Freeman, B.D. Gas solubility, diffusivity and permeability in poly(ethylene oxide). J. Membr. Sci. 2004, 239, 105-117. [CrossRef]

104. Li, K.; Olson, D.H.; Seidel, J.; Emge, T.J.; Gong, H.; Zeng, H.; Li, J. Zeolitic imidazolate frameworks for kinetic separation of propane and propene. J. Am. Chem. Soc. 2009, 131, 10368-10369. [CrossRef]

105. Safarik, D.J.; Eldridge, R.B. Olefin/paraffin separations by reactive absorption: a review. Ind. Eng. Chem. Res. 1998, 37, 2571-2581. [CrossRef]

106. Liu, C.; Osman, Z. High Hydrocarbon Resistant Chemically Cross-Linked Aromatic Polyimide Membrane For Separations. U.S. Patent 9,296,866 B2, 29 March 2016.

107. Feng, X.; Huang, R.Y.M. Liquid Separation by Membrane Pervaporation: A Review. Ind. Eng. Chem. Res. 1997, 36, 1048-1066. [CrossRef]

108. Drioli, E.; Giorno, L. Comprehensive Membrane Science and Engineering; Elsevier: Oxford, UK, 2010; ISBN 9780080932507.

109. Wang, S.; Li, X.; Wu, H.; Tian, Z.; Xin, Q.; He, G.; Peng, D.; Chen, S.; Yin, Y.; Jiang, Z.; et al. Advances in high permeability polymer-based membrane materials for $\mathrm{CO}_{2}$ separations. Energy Environ. Sci. 2016, 9 , 1863-1890. [CrossRef]

110. Merkel, T.; Blanc, R.; Zeid, J.; Suwarlim, A.; Firat, B.; Wijmans, H.; Asaro, M.; Greene, M. Separation of Olefin/Paraffin Mixtures with Carrier Facilitated Membranes; Membrane Technology and Research, Inc.: Menlo Park, CA, USA, 2007.

111. Jiang, B.; Dou, H.; Wang, B.; Sun, Y.; Huang, Z.; Bi, H.; Zhang, L.; Yang, H. Silver-Based Deep Eutectic Solvents as Separation Media: Supported Liquid Membranes for Facilitated Olefin Transport. ACS Sustain. Chem. Eng. 2017, 5, 6873-6882. [CrossRef]

112. Yamaguchi, T.; Baertsch, C.; Koval, C.A.; Noble, R.D.; Bowman, C.N. Olefin separation using silver impregnated ion-exchange membranes and silver salt/polymer blend membranes. J. Membr. Sci. 1996, 117, 151-161. [CrossRef]

113. Kostyanaya, M.; Bazhenov, S.; Borisov, I.; Plisko, T.; Vasilevsky, V. Surface modified polysulfone hollow fiber membranes for ethane/ethylene separation using gas-liquid membrane contactors with ionic liquid-based absorbent. Fibers 2019, 7, 4. [CrossRef]

114. Scholander, P.F. Oxygen Transport through Hemoglobin Solutions. Science 1960, 131, 585-590. [CrossRef]

115. Merkel, T.C.; Blanc, R.; Ciobanu, I.; Firat, B.; Suwarlim, A.; Zeid, J. Silver salt facilitated transport membranes for olefin/paraffin separations: Carrier instability and a novel regeneration method. J. Membr. Sci. 2013, 447, 177-189. [CrossRef]

116. Galizia, M.; Chi, W.S.; Smith, Z.P.; Merkel, T.C.; Baker, R.W.; Freeman, B.D. 50th Anniversary Perspective: Polymers and Mixed Matrix Membranes for Gas and Vapor Separation: A Review and Prospective Opportunities. Macromolecules 2017, 50, 7809-7843. [CrossRef]

117. Rezende, C.G.F. Sorção de Propano e Propeno em Membrana de Poliuretano Contendo Nanopartículas de Prata. Doctorate Dissertation, UFRJ/COPPE, Rio de Janeiro, Brazil, 2016.

118. Ravanchi, M.T.; Kaghazchi, T.; Kargari, A. Effect of Complexation Reaction Constant on the Separation of Propylene/Propane by Supported Liquid Membrane. J. Membr. Sci. Res. 2015, 1, 85-89.

119. Schultz, J.S.; Goddard, J.D.; Suchdeo, S.R. Facilitated transport via carrier-mediated diffusion in membranes: Part I. Mechanistic aspects, experimental systems and characteristic regimes. AIChE J. 1974, 20, 417-445. [CrossRef]

120. Goering, R.M.; Bowman, C.N.; Koval, C.A.; Noble, R.D.; Ashley, M.E. Complexation structure and transport mechanism of 1, 5-hexadiene and 1-hexene through silver facilitated transport membranes. J. Membr. Sci. 2000, 172, 49-57. [CrossRef]

121. Faiz, R.; Fallanza, M.; Boributh, S.; Jiraratananon, R.; Ortiz, I.; Li, K. Long term stability of PTFE and PVDF membrane contactors in the application of propylene/propane separation using AgNO3 solution. Chem. Eng. Sci. 2013, 94, 108-119. [CrossRef]

122. King, C.J. Separation Processes Based on Reversible Chemical Complexation. Handbook of Separation Process Technology; Wiley: New York, NY, USA, 1987.

123. Faiz, R.; Li, K. Olefin/paraffin separation using membrane based facilitated transport/chemical absorption techniques. Chem. Eng. Sci. 2012, 73, 261-284. [CrossRef] 
124. Jose, B.; Ryu, J.H.; Lee, B.G.; Lee, H.; Kang, Y.S.; Kim, H.S. Effect of phthalates on the stability and performance of AgBF4-PVP membranes for olefin/paraffin separation. Chem. Commun. (Camb). 2001, 20, 2046-2047. [CrossRef] [PubMed]

125. Al-Rabiah, A. The Use of Hybrid Membrane/Distillation System for the Ethane/Ethylene Separation in Olefin Plants. In Proceedings of the 4th Ibero-American Congress on Membrane Science and Technology (CITEM); 2003; pp. 1-6.

126. Kuraoka, K.; Matsuura, S.; Ueda, K. Preparation and properties of organic-inorganic hybrid facilitated olefin separation membranes via sol-gel method. Procedia Eng. 2012, 44, 915-917. [CrossRef]

127. Hamza, A.A.; Towe, I.G. Stable Facilitated Transport Membrane for Olefin/Paraffin Separation. In Proceedings of the AIChE Spring Meeting and Global Congress on Process Safety, San Antonio, TX, USA, 2 May 2013.

128. Maghsoudi, H. Comparative study of adsorbents performance in ethylene/ethane separation. Adsorption 2016, 22, 985-992. [CrossRef]

129. Ghasem, N.; Al-Marzouqi, M.; Ismail, Z. Gas-liquid membrane contactor for ethylene/ethane separation by aqueous silver nitrate solution. Sep. Purif. Technol. 2014, 127, 140-148. [CrossRef]

130. Nymeijer, K.; Visser, T.; Assen, R.; Wessling, M. Olefin-Selective Membranes in Gas-Liquid Membrane Contactors for Olefin/Paraffin Separation. Ind. Eng. Chem. Res. 2004, 43, 720-727. [CrossRef]

131. Nymeijer, K.; Visser, T.; Assen, R.; Wessling, M. Super selective membranes in gas-liquid membrane contactors for olefin/paraffin separation. J. Membr. Sci. 2004, 232, 107-114. [CrossRef]

132. GalánSánchez, L.M.; Meindersma, G.W.; Haan, A. Potential of Silver-Based Room-Temperature Ionic Liquids for Ethylene/Ethane Separation. Ind. Eng. Chem. Res. 2009, 48, 10650-10656.

133. Sun, Y.; Bi, H.; Dou, H.; Yang, H.; Huang, Z.; Wang, B.; Deng, R.; Zhang, L. A Novel Copper(I)-Based Supported Ionic Liquid Membrane with High Permeability for Ethylene/Ethane Separation. Ind. Eng. Chem. Res. 2017, 56, 741-749. [CrossRef]

134. Tomé, L.C.; Mecerreyes, D.; Freire, C.S.R.; Rebelo, L.P.N.; Marrucho, I.M. Polymeric ionic liquid membranes containing IL-Ag+ for ethylene/ethane separation via olefin-facilitated transport. J. Mater. Chem. A 2014, 2, 5631. [CrossRef]

135. Jiang, B.; Dou, H.; Zhang, L.; Wang, B.; Sun, Y.; Yang, H.; Huang, Z.; Bi, H. Novel supported liquid membranes based on deep eutectic solvents for olefin-paraffin separation via facilitated transport. J. Membr. Sci. 2017, 536, 123-132. [CrossRef]

136. Nymeijer, D.C.; Visser, T.; Assen, R.; Wessling, M. Composite hollow fiber gas-liquid membrane contactors for olefin/paraffin separation. Sep. Purif. Technol. 2004, 37, 209-220. [CrossRef]

137. Eriksen, O.I.; Aksnes, E.; Dahl, I.M. Facilitated transport of ethene through Nafion membranes. Part II. Glycerine treated, water swollen membranes. J. Membr. Sci. 1993, 85, 99-106. [CrossRef]

138. Su, C.; Kuraoka, K.; Yazawa, T. Ethene/Ethane (C2H4/C2H6) Separation through an Inorganic-Organic Hybrid Membrane Containing Silver (I) Ions as Olefin Carriers, Using Poly(N-vinylpyrrolidone) as a Mediation Agent. J. Am. Ceram. Soc. 2001, 84, 654-656. [CrossRef]

139. Pinnau, I.; Toy, L.G. Solid polymer electrolyte composite membranes for olefin/paraffin separation. J. Membr. Sci. 2001, 184, 39-48. [CrossRef]

140. Müller, J.; Peinemann, K.V.; Müller, J. Development of facilitated transport membranes for the separation of olefins from gas streams. Desalination 2002, 145, 339-345. [CrossRef]

141. Teramoto, M.; Takeuchi, N.; Maki, T.; Matsuyama, H. Ethylene/ethane separation by facilitated transport membrane accompanied by permeation of aqueous silver nitrate solution. Sep. Purif. Technol. 2002, 28, 117-124. [CrossRef]

142. Morisato, A.; He, Z.; Pinnau, I.; Merkel, T.C. Transport properties of PA12-PTMO/AgBF4 solid polymer electrolyte membranes for olefin/paraffin separation. Desalination 2002, 145, 347-351. [CrossRef]

143. Kim, J.H.; Min, B.R.; Kim, H.S.; Won, J.; Kang, Y.S. Facilitated transport of ethylene across polymer membranes containing silver salt: effect of HBF4 on the photoreduction of silver ions. J. Membr. Sci. 2003, 212, 283-288. [CrossRef]

144. Teramoto, M.; Shimizu, S.; Matsuyama, H.; Matsumiya, N. Ethylene/ethane separation and concentration by hollow fiber facilitated transport membrane module with permeation of silver nitrate solution. Sep. Purif. Technol. 2005, 44, 19-29. [CrossRef] 
145. Hamouda, S.B.; Nguyen, Q.T.; Langevin, D.; Schaetzel, P.; Roudesli, S. Fine characterization of the ethylene and ethane sorption in poly(amide 12-block-tetramethylenoxide) copolymer/AgBF4 membranes. Eur. Polym. J. 2006, 42, 2994-3005. [CrossRef]

146. Lee, J.S.; Ko, N.H.; Bae, H.W.; Nguyen, D.Q.; Lee, H.; Choi, D.K.; Cheong, M.; Kim, H.S. Effect of ester group on the performance of zwitterionic imidazolium compounds as membrane materials for separating alkene/alkane mixtures. J. Membr. Sci. 2008, 313, 344-352. [CrossRef]

147. Kuraoka, K.; Matsuura, S.; Ueda, K. Ethylene/Ethane Separation through a $\mathrm{SiO}_{2}-\mathrm{Poly}\left(\right.$ sodium acrylate)-Ag ${ }^{+}$ Organic-Inorganic Hybrid Membrane. Chem. Lett. 2014, 43, 582-583. [CrossRef]

148. Ovcharova, A.; Vasilevsky, V.; Borisov, I.; Bazhenov, S.; Volkov, A.; Bildyukevich, A.; Volkov, V. Polysulfone porous hollow fiber membranes for ethylene-ethane separation in gas-liquid membrane contactor. Sep. Purif. Technol. 2017, 183, 162-172. [CrossRef]

149. Malakhov, A.O.; Bazhenov, S.D.; Vasilevsky, V.P.; Borisov, I.L.; Ovcharova, A.A.; Bildyukevich, A.V.; Volkov, V.V.; Giorno, L.; Volkov, A.V. Thin-film composite hollow fiber membranes for ethylene/ethane separation in gas-liquid membrane contactor. Sep. Purif. Technol. 2019, 219, 64-73. [CrossRef]

150. Kim, H.S.; Ryu, J.H.; Kim, H.; Ahn, B.S.; Kang, Y.S. Reversible olefin complexation by silver ions in dry poly(vinyl methyl ketone) membrane and its application to olefin/paraffin separations. Chem. Commun. 2000, 1261-1262. [CrossRef]

151. Liu, L.; Feng, X.; Chakma, A. Unusual behavior of poly(ethylene oxide)/AgBF4 polymer electrolyte membranes for olefin-paraffin separation. Sep. Purif. Technol. 2004, 38, 255-263. [CrossRef]

152. Grande, C.A.; Araujo, J.D.P.; Cavenati, S.; Firpo, N.; Basaldella, E.; Rodrigues, A.E. New $\pi$-Complexation Adsorbents for Propane-Propylene Separation. Langmuir 2004, 20, 5291-5297. [CrossRef]

153. Stoitsas, K.A.; Gotzias, A.; Kikkinides, E.S.; Steriotis, T.A.; Kanellopoulos, N.K.; Stoukides, M.; Zaspalis, V.T. Porous ceramic membranes for propane-propylene separation via the $\pi$-complexation mechanism: Unsupported systems. Microporous Mesoporous Mater. 2005, 78, 235-243. [CrossRef]

154. Kang, S.W.; Kim, J.H.; Char, K.; Won, J.; Kang, Y.S. Nanocomposite silver polymer electrolytes as facilitated olefin transport membranes. J. Membr. Sci. 2006, 285, 102-107. [CrossRef]

155. Kang, S.W.; Hong, J.; Char, K.; Kim, J.H.; Kim, J.; Kang, Y.S. Correlation between anions of ionic liquids and reduction of silver ions in facilitated olefin transport membranes. Desalination 2008, 233, 327-332. [CrossRef]

156. Kang, S.W.; Kang, Y.S. Silver nanoparticles stabilized by crosslinked poly(vinyl pyrrolidone) and its application for facilitated olefin transport. J. Colloid Interface Sci. 2011, 353, 83-86. [CrossRef] [PubMed]

157. Fallanza, M.; Ortiz, A.; Gorri, D.; Ortiz, I. Polymer-ionic liquid composite membranes for propane/propylene separation by facilitated transport. J. Membr. Sci. 2013, 444, 164-172. [CrossRef]

158. Faiz, R.; Fallanza, M.; Ortiz, I.; Li, K. Separation of Olefin Paraffin Gas Mixtures Using Ceramic Hollow Fiber Membrane Contactors. Ind. Eng. Chem. Res. 2013, 52, 7918-7929. [CrossRef]

159. Fallanza, M.; Ortiz, A.; Gorri, D.; Ortiz, I. Using membrane reactive absorption modeling to predict optimum process conditions in the separation of propane-propylene mixtures. Ind. Eng. Chem. Res. 2013, 52, 8843-8855. [CrossRef]

160. Sun, H.; Ma, C.; Wang, T.; Xu, Y.; Yuan, B.; Kong, Y. Satellite TiO2nanoparticles induced by silver ion in polymer electrolytes membrane for propylene/propane separation. Mater. Chem. Phys. 2014, 148, 790-797. [CrossRef]

161. Hamza, A.A.; Martin, J.; Perez, J.C. Continuous Olefin/Paraffin Separation with Permylene ${ }^{\mathrm{TM}}$ Facilitated Transport Membranes from Imtex Membranes Corp. In Proceedings of the AIChE Spring Meeting and Global Congress on Process Safety, Austin, TX, USA, 29 April 2015.

162. Park, C.H.; Lee, J.H.; Jung, J.P.; Kim, J.H. Mixed matrix membranes based on dual-functional MgO nanosheets for olefin/paraffin separation. J. Membr. Sci. 2017, 533, 48-56. [CrossRef]

163. Kang, S.W.; Char, K.; Kim, J.H.; Kim, C.K.; Kang, Y.S. Control of ionic interactions in silver salt-polymer complexes with ionic liquids: Implications for facilitated olefin transport. Chem. Mater. 2006, 18, 1789-1794. [CrossRef]

164. Chang, J.W.; Marrero, T.R.; Yasuda, H.K. Continuous process for propylene/propane separation by use of silver nitrate carrier and zirconia porous membrane. J. Membr. Sci. 2002, 205, 91-102. [CrossRef]

165. Duan, S.; Ito, A.; Ohkawa, A. Separation of propylene/propane mixture by a supported liquid membrane containing triethylene glycol and a silver salt. J. Membr. Sci. 2003, 215, 53-60. [CrossRef] 
166. Chilukuri, P.; Rademakers, K.; Nymeijer, K.; Ham, L. Van Der Propylene/Propane Separation with a Gas/Liquid Membrane Contactor Using a Silver Salt Solution. Ind. Eng. Chem. Res. 2007, 8701-8709. [CrossRef]

167. Takhtravanchi, M.; Kaghazchi, T.; Kargari, A. Immobilized Liquid Membrane for Propylene- Propane Separation. Proc. World Acad. Sci. Eng. Technol. 2008, 79-81.

168. Kang, S.W.; Char, K.; Kang, Y.S. Novel Application of Partially Positively Charged Silver Nanoparticles for Facilitated Transport in Olefin/Paraffin Separation Membranes. Chem. Mater. 2008, 1308-1311. [CrossRef]

169. Ortiz, A.; Ruiz, A.; Gorri, D.; Ortiz, I. Room temperature ionic liquid with silver salt as efficient reaction media for propylene/propane separation: Absorption equilibrium. Sep. Purif. Technol. 2008, 63, 311-318. [CrossRef]

170. Takht Ravanchi, M.; Kaghazchi, T.; Kargari, A.; Soleimani, M. A novel separation process for olefin gas purification: Effect of operating parameters on separation performance and process optimization. J. Taiwan Inst. Chem. Eng. 2009, 40, 511-517. [CrossRef]

171. Ravanchi, M.T.; Kaghazchi, T.; Kargari, A. Separation of propylene-propane mixture using immobilized liquid membrane via facilitated transport mechanism. Sep. Sci. Technol. 2009, 44, 1198-1217. [CrossRef]

172. Ravanchi, M.T.; Kaghazchi, T.; Kargari, A. Facilitated transport separation of propylene-propane: Experimental and modeling study. Chem. Eng. Process. Process Intensif. 2010, 49, 235-244. [CrossRef]

173. Agel, F.; Pitsch, F.; Krull, F.F.; Schulz, P.; Wessling, M.; Melin, T.; Wasserscheid, P. Ionic liquid silver salt complexes for propene/propane separation. Phys. Chem. Chem. Phys. 2011, 13, 725-731. [CrossRef]

174. Ortiz, A.; Marı, L.; Gorri, D.; De Haan, B.; Ortiz, I. Reactive Ionic Liquid Media for the Separation of Propylene/Propane Gaseous Mixtures. Ind. Eng. Chem. Res. 2010, 49, 7227-7233. [CrossRef]

175. Ravanchi, M.T.; Kaghazchi, T.; Kargari, A. Supported liquid membrane separation of propylene-propane mixtures using a metal ion carrier. Desalination 2010, 250, 130-135. [CrossRef]

176. Fallanza, M.; Ortiz, A.; Gorri, D.; Ortiz, I. Experimental study of the separation of propane/propylene mixtures by supported ionic liquid membranes containing Ag+-RTILs as carrier. Sep. Purif. Technol. 2012, 97, 83-89. [CrossRef]

177. Faiz, R.; Fallanza, M.; Ortiz, I.; Li, K. Olefin/paraffin separation using ceramic hollow fiber membrane contactors. Procedia Eng. 2012, 44, 662-665. [CrossRef]

178. Kasahara, S.; Kamio, E.; Minami, R.; Matsuyama, H. A facilitated transport ion-gel membrane for propylene/propane separation using silver ion as a carrier. J. Membr. Sci. 2013, 431, 121-130. [CrossRef]

179. Hong, G.H.; Ji, D.; Kang, S.W. Highly permeable ionic liquid/Cu composite membrane for olefin/paraffin separation. Chem. Eng. J. 2013, 230, 111-114. [CrossRef]

180. Azizi, S.; Kaghazchi, T.; Kargari, A. Propylene/propane separation using N-methyl pyrrolidone/AgNO3 supported liquid membrane. J. Taiwan Inst. Chem. Eng. 2015, 57, 1-8. [CrossRef]

181. Kim, J.H.; Min, B.R.; Lee, K.B.; Won, J.; Kang, Y.S. Coordination structure of various ligands in crosslinked PVA to silver ions for facilitated olefin transport. Chem. Commun. 2002, 2, 2732-2733. [CrossRef]

182. Zarca, R.; Ortiz, A.; Gorri, D.; Biegler, L.T.; Ortiz, I. Optimization of multistage olefin/paraffin membrane separation processes through rigorous modeling. AIChE J. 2019. [CrossRef]

183. Bai, S.; Sridhar, S.; Khan, A.A. Metal-ion mediated separation of propylene from propane using PPO membranes. J. Membr. Sci. 1998, 147, 131-139. [CrossRef]

184. Kim, Y.H.; Ryu, H.; Bae, Y.; Kang, S.; Sik, H. Reactive polymer membranes containing cuprous complexes in olefin/paraffin separation. Chem. Commun. 2000, 3, 195-196. [CrossRef]

185. Park, Y.S.; Won, J.; Kang, Y.S. Preparation of Poly ( ethylene glycol ) Brushes on Polysulfone Membranes for Olefin/Paraffin Separation. Macromolecules 2000, 16, 9662-9665. [CrossRef]

186. Hong, S. Effect of water on the facilitated transport of olefins through solid polymer electrolyte membranes. J. Membr. Sci. 2001, 181, 289-293. [CrossRef]

187. Sunderrajan, S.; Freeman, B.D.; Hall, C.K.; Pinnau, I. Propane and propylene sorption in solid polymer electrolytes based on poly(ethylene oxide) and silver salts. J. Membr. Sci. 2001, 182, 1-12. [CrossRef]

188. Jose, B.; Ryu, J.H.; Kim, Y.J.; Kim, H.; Kang, Y.S.; Lee, S.D.; Kim, H.S. Effect of Plasticizers on the Formation of Silver Nanoparticles in Polymer Electrolyte Membranes for Olefin/Paraffin Separation. Chem. Mater. 2002, 14, 2134-2139. [CrossRef]

189. Kim, J.H.; Min, B.R.; Won, J.; Kang, Y.S. Anomalous temperature dependence of facilitated propylene transport in silver polymer electrolyte membranes. J. Membr. Sci. 2003, 227, 197-206. [CrossRef] 
190. Hun Park, H.; Won, J.; Oh, S.G.; Kang, Y.S. Effect of nonionic n-octyl $\beta$-D-glucopyranoside surfactant on the stability improvement of silver polymer electrolyte membranes for olefin/paraffin separation. J. Membr. Sci. 2003, 217, 285-293. [CrossRef]

191. Kim, J.H.; Min, B.R.; Won, J.; Kang, Y.S. Revelation of facilitated olefin transport through silver-polymer complex membranes using anion complexation. Macromolecules 2003, 36, 4577-4581. [CrossRef]

192. Kim, J.H.; Park, S.M.; Won, J.; Kang, Y.S. Dependence of facilitated olefin transport on the thickness of silver polymer electrolyte membranes. J. Membr. Sci. 2004, 236, 209-212. [CrossRef]

193. Kim, J.H.; Won, J.; Kang, Y.S. Olefin-induced dissolution of silver salts physically dispersed in inert polymers and their application to olefin/paraffin separation. J. Membr. Sci. 2004, 241, 403-407. [CrossRef]

194. Kim, J.H.; Won, J.; Kang, Y.S. Silver polymer electrolytes by $\pi$-complexation of silver ions with polymer containing $\mathrm{C}=\mathrm{C}$ bond and their application to facilitated olefin transport membranes. J. Membr. Sci. 2004, 237, 199-202. [CrossRef]

195. Kang, S.W.; Kim, J.H.; Won, J.; Char, K.; Kang, Y.S. Effect of amino acids in polymer/silver salt complex membranes on facilitated olefin transport. J. Membr. Sci. 2005, 248, 201-206. [CrossRef]

196. Kim, J.H.; Kim, C.K.; Won, J.; Kang, Y.S. Role of anions for the reduction behavior of silver ions in polymer/silver salt complex membranes. J. Membr. Sci. 2005, 250, 207-214. [CrossRef]

197. Kim, J.H.; Park, S.M.; Won, J.; Kang, Y.S. Unusual separation property of propylene/propane mixtures through polymer/silver complex membranes containing mixed salts. J. Membr. Sci. 2005, 248, 171-176. [CrossRef]

198. Hess, S.; Staudt-Bickel, C.; Lichtenthaler, R.N. Propene/propane separation with copolyimide membranes containing silver ions. J. Membr. Sci. 2006, 275, 52-60. [CrossRef]

199. Lee, D.H.; Kang, Y.S.; Kim, J.H.; Kang, S.W. Selective coordination of silver ions to poly(styrene-b-(ethylene-cobutylene)-b-styrene) and its influence on morphology and facilitated olefin transport. Macromol. Res. 2008, 16, 676-681. [CrossRef]

200. Mun, S.H.; Kang, S.W.; Cho, J.S.; Koh, S.K.; Kang, Y.S. Enhanced olefin carrier activity of clean surface silver nanoparticles for facilitated transport membranes. J. Membr. Sci. 2009, 332, 1-5. [CrossRef]

201. Koh, J.H.; Kang, S.W.; Park, J.T.; Seo, J.A.; Kim, J.H.; Kang, Y.S. Synthesis of silver halide nanocomposites templated by amphiphilic graft copolymer and their use as olefin carrier for facilitated transport membranes. J. Membr. Sci. 2009, 339, 49-56. [CrossRef]

202. Wang, Y.; Ren, J.; Deng, M. Ultrathin solid polymer electrolyte PEI/Pebax2533/AgBF 4 composite membrane for propylene/propane separation. Sep. Purif. Technol. 2011, 77, 46-52. [CrossRef]

203. Pollo, L.D.; Duarte, L.T.; Anacleto, M.; Habert, A.C.; Borges, C.P. Polymeric membranes containing silver salts for propylene/propane separation. Brazilian J. Chem. Eng. 2012, 29, 307-314. [CrossRef]

204. Fallanza, M.; Ortiz, A.; Gorri, D.; Ortiz, I. Effect of liquid flow on the separation of propylene/propane mixtures with a gas/liquid membrane contactor using $\mathrm{Ag}^{+}$-RTIL solutions. Desalin. Water Treat. 2011, 27, 123-129. [CrossRef]

205. Najari, S.; Omidkhah, M.; Saeid, S. An Investigation on the Factors Affecting the Properties and Performance of Polymeric Nanocomposite Membranes for Olefin/Paraffin Separation. In Proceedings of the 5th International Conference on Ultrafine Grained and Nanostructured Materials, Tehran, Iran, 11-12 November 2015.

206. Surya Murali, R.; Yamuna Rani, K.; Sankarshana, T.; Ismail, A.F.; Sridhar, S. Separation of Binary Mixtures of Propylene and Propane by Facilitated Transport through Silver Incorporated Poly(Ether-Block-Amide) Membranes. Oil Gas Sci. Technol. - Rev. d'IFP Energies Nouv. 2015, 70, 381-390. [CrossRef]

207. Majumdar, S.; Koizumi, Y.; Loprete, K.; Pennisi, K.; Nemser, S.; Feiring, A.; Shangguan, N.; Murnen, H.; Lousenberg, D. Olefin-paraffin separation with customized amorphous fluoropolymer (CAF) facilitated transport membranes. In Proceedings of the 29th Ethylene Producers Conference 2017-Topical Conference at the 2017 AIChE Spring Meeting and 13th Global Congress on Process Safety, San Antonio, TX, USA, 28 March 2017.

208. Jung, J.P.; Kim, M.J.; Bae, Y.S.; Kim, J.H. Facile preparation of Cu(I) impregnated MIL-101(Cr) and its use in a mixed matrix membrane for olefin/paraffin separation. J. Appl. Polym. Sci. 2018, 135, 46545. [CrossRef]

209. Hsiue, G.H.; Yang, J.S. Polymeric complex membranes for olefin/paraffin separation. In Macromolecular Symposia; Hüthig \& Wepf Verlag: Basel, Switzerland, 1996.

210. Liu, J.; Chen, X.; Zhao, S.; Cao, X.; Shen, B. Multicycle Investigation of Normal Paraffin Separation from Naphtha To Improve Olefin and Aromatic Feed. Ind. Eng. Chem. Res. 2015, 54, 12664-12670. [CrossRef] 
211. Grande, C.A.; Lind, A.; Vistad, Ø.; Akporiaye, D. Olefin-Paraffin Separation Using Calcium-ETS-4. Ind. Eng. Chem. Res. 2014, 53, 15522-15530. [CrossRef]

212. Son, S.J.; Choi, H.W.; Choi, D.K.; Lee, S.D.; Kim, H.S.; Kim, S.W. Selective absorption of isoprene from C5 mixtures by $\pi$ complexation with $\mathrm{Cu}(\mathrm{I})$. Ind. Eng. Chem. Res. 2005, 44, 4717-4720. [CrossRef]

213. Naghsh, M.; Sadeghi, M.; Moheb, A.; Chenar, M.P.; Mohagheghian, M. Separation of ethylene/ethane and propylene/propane by cellulose acetate-silica nanocomposite membranes. J. Membr. Sci. 2012, 423-424, 97-106. [CrossRef]

214. Kanezashi, M.; Kawano, M.; Yoshioka, T.; Tsuru, T. Organic À Inorganic Hybrid Silica Membranes with Controlled Silica Network Size for Propylene/Propane Separation. Ind. Eng. Chem. Res. 2012, 51, 944-953. [CrossRef]

215. Xu, L.; Rungta, M.; Koros, W.J. Matrimid®derived carbon molecular sieve hollow fiber membranes for ethylene/ethane separation. J. Membr. Sci. 2011, 380, 138-147. [CrossRef]

216. Rungta, M.; Xu, L.; Koros, W.J. Carbon molecular sieve dense film membranes derived from Matrimid@for ethylene/ethane separation. Carbon 2012, 50, 1488-1502. [CrossRef]

217. Motelica, A.; Bruinsma, O.S.L.; Kreiter, R.; den Exter, M.; Vente, J.F. Membrane Retrofit Option for Paraffin/Olefin Separation-A Technoeconomic Evaluation. Ind. Eng. Chem. Res. 2012, 51, 6977-6986. [CrossRef]

218. Xu, L.; Rungta, M.; Brayden, M.K.; Martinez, M.V.; Stears, B.A.; Barbay, G.A.; Koros, W.J. Olefins-selective asymmetric carbon molecular sieve hollow fiber membranes for hybrid membrane-distillation processes for olefin/paraffin separations. J. Membr. Sci. 2012, 423-424, 314-323. [CrossRef]

219. Salinas, O.; Ma, X.; Litwiller, E.; Pinnau, I. High-performance carbon molecular sieve membranes for ethylene/ethane separation derived from an intrinsically microporous polyimide. J. Membr. Sci. 2016, 500, 115-123. [CrossRef]

220. Brayden, M. Impact of impurities on carbon molecular sieve membranes. In Proceedings of the AIChE Spring Meeting and Global Congress on Process Safety, San Antonip, TX, USA, 26-30 March 2017.

221. Brayden, M.; Koros, W.J.; Xu, L.; Martinez, M.; Stears, B.A.; Barbay, G.A. Carbon Molecular Sieve Hollow Fiber Membranes for Olefin/Paraffin Separations. In Proceedings of the 2013 Spring Meeting and 9th Global Congress on Process Safety, San Antonio, TX, USA, 2 May 2013.

222. Das, M. Membranes for Olefin/Paraffin Separations. Doctorate dissertation, Georgia Institute of Technology, Atlanta, GA, USA, 2009.

223. Ma, X.; Lin, B.K.; Wei, X.; Kniep, J.; Lin, Y.S. Gamma-Alumina Supported Carbon Molecular Sieve Membrane for Propylene/Propane Separation. Ind. Eng. Chem. Res. 2013, 52, 4297-4305. [CrossRef]

224. Ma, X.; Williams, S.; Wei, X.; Kniep, J.; Lin, Y.S. Propylene/Propane Mixture Separation Characteristics and Stability of Carbon Molecular Sieve Membranes. Ind. Eng. Chem. Res. 2015, 54, 9824-9831. [CrossRef]

225. Mei, L.; Wu, Y.; Zhou, X.; Yan, J.; Xu, F.; Li, Z. Adsorption performance of MIL-100(Fe) for separation of olefin-paraffin mixtures. J. Taiwan Inst. Chem. Eng. 2017, 70, 74-78. [CrossRef]

226. Lin, Y.; Ji, W.; Wang, Y. Cuprous-Chloride-Modified Nanoporous Alumina Membranes for Ethylene-Ethane Separation. Ind. Eng. Chem. Res. 1999, 38, 2292-2298. [CrossRef]

227. Van Miltenburg, A.; Zhu, W.; Kapteijn, F.; Moulijn, J.A. Adsorptive separation of light olefin/paraffin mixtures. Chem. Eng. Res. Des. 2006, 84, 350-354. [CrossRef]

228. Shi, M.; Lin, C.C.H.; Kuznicki, T.M.; Hashisho, Z.; Kuznicki, S.M. Separation of a binary mixture of ethylene and ethane by adsorption on Na-ETS-10. Chem. Eng. Sci. 2010, 65, 3494-3498. [CrossRef]

229. Aguado, S.; Bergeret, G.; Daniel, C.; Farrusseng, D. Absolute molecular sieve separation of ethylene/ethane mixtures with silver zeolite A. J. Am. Chem. Soc. 2012, 134, 14635-14637. [CrossRef]

230. Hovestadt, M.; Friebe, S.; Helmich, L.; Lange, M.; Möllmer, J.; Gläser, R.; Mundstock, A.; Hartmann, M. Continuous Separation of light olefin/paraffin mixtures on ZIF-4 by pressure swing adsorption and membrane permeation. Molecules 2018, 23, 889. [CrossRef]

231. Hartmann, M.; Böhme, U.; Hovestadt, M.; Paula, C. Adsorptive Separation of Olefin/Paraffin Mixtures with ZIF-4. Langmuir 2015, 31, 12382-12389. [CrossRef] [PubMed]

232. Sakai, M.; Sasaki, Y.; Tomono, T.; Seshimo, M.; Matsukata, M. Olefin Selective Ag-Exchanged X-Type Zeolite Membrane for Propylene/Propane and Ethylene/Ethane Separation. ACS Appl. Mater. Interfaces 2019, 11, 4145-4151. [CrossRef] [PubMed] 
233. Chu, Y.H.; Yancey, D.; Xu, L.; Martinez, M.; Brayden, M.; Koros, W. Iron-containing carbon molecular sieve membranes for advanced olefin/paraffin separations. J. Membr. Sci. 2018, 548, 609-620. [CrossRef]

234. Ploegmakers, J.; Japip, S.; Nijmeijer, K. Mixed matrix membranes containing MOFs for ethylene/ethane separation Part A: Membrane preparation and characterization. J. Membr. Sci. 2013, 428, 445-453. [CrossRef]

235. Pires, J.; Pinto, L.; Saini, V.K. Ethane Selective IRMOF-8 and Its Signi fi cance in Ethane-Ethylene Separation by Adsorption. ACS Appl. Mater. Interfaces 2014, 6, 12093-12099. [CrossRef] [PubMed]

236. Chang, G.; Bao, Z.; Ren, Q.; Deng, S.; Zhang, Z.; Su, B.; Xing, H.; Yang, Y. Fabrication of cuprous nanoparticles in MIL-101: An efficient adsorbent for the separation of olefin-paraffin mixtures. RSC Adv. 2014, 4, 20230-20233. [CrossRef]

237. Luna-Triguero, A.; Vicent-Luna, J.M.; Becker, T.M.; Vlugt, T.J.H.; Dubbeldam, D.; Gómez-Álvarez, P.; Calero, S. Effective Model for Olefin/Paraffin Separation using (Co, Fe, Mn, Ni)-MOF-74. ChemistrySelect 2017, 2, 665-672. [CrossRef]

238. Böhme, U.; Barth, B.; Paula, C.; Kuhnt, A.; Schwieger, W.; Mundstock, A.; Caro, J.; Hartmann, M. Ethene/ethane and propene/propane separation via the olefin and paraffin selective metal-organic framework adsorbents CPO-27 and ZIF-8. Langmuir 2013, 29, 8592-8600. [CrossRef]

239. Kulkarni, A.R.; Sholl, D.S. Screening of Copper Open Metal Site MOFs for Olefin/Paraffin Separations Using DFT-Derived Force Fields. J. Phys. Chem. C 2016, 120, 23044-23054. [CrossRef]

240. Bendt, S.; Hovestadt, M.; Böhme, U.; Paula, C.; Döpken, M.; Hartmann, M.; Keil, F.J. Olefin/Paraffin Separation Potential of ZIF-9 and ZIF-71: A Combined Experimental and Theoretical Study. Eur. J. Inorg. Chem. 2016, 2016, 4440-4449. [CrossRef]

241. Zhou, S.; Wei, Y.; Li, L.; Duan, Y.; Hou, Q.; Zhang, L.; Ding, L.X.; Xue, J.; Wang, H.; Caro, J. Paralyzed membrane: Current-driven synthesis of a metal-organic framework with sharpened propene/propane separation. Sci. Adv. 2018, 4, eaau1393. [CrossRef] [PubMed]

242. Askari, M.; Chung, T.S. Natural gas purification and olefin/paraffin separation using thermal cross-linkable co-polyimide/ZIF-8 mixed matrix membranes. J. Membr. Sci. 2013, 444, 173-183. [CrossRef]

243. Cadiau, A.; Adil, K.; Bhatt, P.M.; Belmabkhout, Y.; Eddaoudi, M. A metal-organic framework-based splitter for separating propylene from propane. Science 2016, 353, 137-140. [CrossRef] [PubMed]

244. Yong, S.K.; Kook Heon Char, S.; Sang Wook Kang, S.; Moon, S.-H. Facilitated olefin transporting polymer membrane containing metal nanoparticle. WO Patent 2007117087A1, 18 October 2007.

245. Matsukata, M.; Seshimo, M.; Sakai, M.; Kimura, O.; Adachi, M. Olefin separation method and zeolite membrane complex. WO Patent 2015141686A1, 24 September 2015.

246. Koros, W.J.; Xu, L.; Brayden, M.K.; Martinez, M.V.; Stears, B.A. A hollow fiber carbon molecular sieve membrane and preparation and use thereof. U.S. Patent 9,346,011, 24 May 2016.

247. Long, J.R.; Herm, Z.R.; Swisher, J.A.; Smit, B.; Krishna, R.; Bloch, E.; Murray, L. Metal-Organic Framework Adsorbents for Composite Gas Separation. U.S. Patent 13/965,098, 6 March 2014.

248. Kim, H.S.; Kang, Y.S.; Lee, B.G.; Lee, H.J.; Ryu, J.H. Method for Producing Silver Salt-Containing Facilitated Transport Membrane for Olefin Separation Having Improved Stability. U.S. Patent 6,878,409, 12 April 2005.

249. Kang, Y.S.; Char, K.H.; Kang, S.W. Silver Nanoparticle/Polymer Nanocomposite Membranes for Olefin Paraffin Separation and Method of Preparing the Same. U.S. Patent 7,491,262, 17 February 2009.

250. Kang, Y.S.; Jung, B.; Kim, J.; Won, J.; Char, K.H.; Kang, S.W. Facilitated Transport Membranes for an Alkene Hydrocarbon Separation. U.S. Patent 11/011, 14 July 2005.

251. Feiring, A.E.; Wilmington, D.; Lazzeri, J.; Ventura, C.; Majumdar, S.; Newark, D. Membrane Separation of Olefin and Paraffn Mixtures. U.S. Patent 20150025293A1, 22 January 2015.

252. Liu, C.; Arlington Heights, I.; Liskey, C.W.; Tran, H.O.; Karns, N.K. High Selectivity Facilitated Transport Membranes and Their Use for Olefin/Paraffin Separation. U.S. Patent 20170354918A1, 14 December 2017.

253. Liu, C.; Karns, N.K. Stable Facilitated Transport Membranes for Olefin/Paraffin Separations. U.S. Patent Application 10/258,929, 16 April 2019.

254. Sheikholeslami, R. Fouling mitigation in membrane processes. Desal. J. 1999, 123, 45-53. [CrossRef]

255. Van Zyl, A.J.; Kerres, J.A.; Cui, W.; Junginger, M. Application of new sulfonated ionomer membranes in the separation of pentene and pentane by facilitated transport. J. Membr. Sci. 1997, 137, 173-185. [CrossRef]

256. Kovvali, A.S.; Chen, H.; Sirkar, K.K. Glycerol-based immobilized liquid membranes for olefin-paraffin separation. Ind. Eng. Chem. Res. 2002, 41,347-356. [CrossRef] 
257. Jiang, B.; Tao, W.; Dou, H.; Sun, Y.; Xiao, X.; Zhang, L.; Yang, N. A Novel Supported Liquid Membrane Based on Binary Metal Chloride Deep Eutectic Solvents for Ethylene/Ethane Separation. Ind. Eng. Chem. Res. 2017, 56, 15153-15162. [CrossRef]

258. Yang, J.S.; Hsiue, G.H. C4 olefin/paraffin separation by poly[(1-trimethylsilyl)-1-propyne]-graft-poly(acrylic acid)- $\mathrm{Ag}^{+}$complex membranes. J. Membr. Sci. 1996, 111, 27-38. [CrossRef]

259. Choi, H.W.; Kim, D.B.; Choi, D.K.; Ahn, B.S.; Kim, H.G.; Kim, H.S.; Lee, C.H.; Sung, J.Y. Highly selective facilitated transport membranes for isoprene/n-pentane separation. J. Membr. Sci. 2006, 279, 403-409. [CrossRef]

260. Van Zyl, A.J.; Linkov, V.M. Influence of oxygen-containing hydrocarbons on the separation of olefin/paraffin mixtures using facilitated transport. J. Membr. Sci. 1997, 133, 15-26. [CrossRef]

261. Ma, L.; Svec, F.; Tan, T.; Lv, Y. Mixed Matrix Membrane Based on Cross-Linked Poly[(ethylene glycol) methacrylate] and Metal-Organic Framework for Efficient Separation of Carbon Dioxide and Methane. ACS Appl. Nano Mater. 2018, 1, 2808-2818. [CrossRef]

262. Chai, S.; Du, H.; Zhao, Y.; Lin, Y.; Kong, C.; Chen, L. Fabrication of highly selective organosilica membrane for gas separation by mixing bis(triethoxysilyl)ethane with methyltriethoxysilane. Sep. Purif. Technol. 2019, 222, 162-167. [CrossRef]

263. Sun, Q.; Qi, B.; Liu, A.; Guo, X.; Zhang, J. Separation of $\mathrm{H} 2 / \mathrm{CH}_{4}$ Through TBAB Hydrate Membrane. Int. J. New Technol. Sci. Eng. 2015, 2, 39-46.

264. Bandehali, S.; Kargari, A.; Moghadassi, A.; Saneepur, H.; Ghanbari, D. Acrylonitrile-butadiene-styrene/ poly(vinyl acetate)/nanosilica mixed matrix membrane for $\mathrm{He} / \mathrm{CH}_{4}$ separation. Asia-Pacific J. Chem. Eng. 2014, 9, 638-644. [CrossRef]

265. Lei, G.; Liu, C.; Xie, H.; Song, F. Separation of the hydrogen sulfide and methane mixture by the porous graphene membrane: Effect of the charges. Chem. Phys. Lett. 2014, 599, 127-132. [CrossRef]

266. Sklari, S.D.; Zaspalis, V.T. A novel system of Al100P60Ozmicroporous ceramic membrane for hydrogen separation from hydrogen/propane mixtures. Microporous Mesoporous Mater. 2007, 99, 176-180. [CrossRef]

267. Bux, H.; Feldhoff, A.; Cravillon, J.; Wiebcke, M.; Li, Y.S.; Caro, J. Oriented zeolitic imidazolate framework-8 membrane with sharp H 2/C3H8 molecular sieve separation. Chem. Mater. 2011, 23, 2262-2269. [CrossRef]

268. Sadrzadeh, M.; Shahidi, K.; Mohammadi, T. Preparation and C3H8/gas separation properties of a synthesized single layer PDMS membrane. Sep. Sci. Technol. 2010, 45, 592-603. [CrossRef]

269. Chen, J.; Eldridge, R.B.; Rosen, E.L.; Bielawski, C.W. A study of Cu(I)-ethylene complexation for olefin-paraffin separation. AIChE J. 2011, 57, 630-644. [CrossRef]

270. Da Costa, A.R.; Wijmans, H.; Baker, R.W. Ethylene Recovery by Membrane Technology. Proceedings of the 13th Ethylene Producers' Conference, Houston, TX. 2001, pp. 78-87. Available online: https://www.tib.eu/en/search/ id/BLCP\%3ACN046215552/Ethylene-Recovery-by-Membrane-Technology/ (accessed on 7 November 2019).

271. Yu, L.; Grahn, M.; Ye, P.; Hedlund, J. Ultra-thin MFI membranes for olefin/nitrogen separation. J. Membr. Sci. 2017, 524, 428-435. [CrossRef]

272. Ho, W.S.; Dalrymple, D.C. Facilitated transport of olefins in Ag+-containing polymer membranes. J. Membr. Sci. 1994, 91, 13-25. [CrossRef]

273. Funke, H.H.; Noble, R.D.; Koval, C.A. Separation of gaseous olefin isomers using facilitated transport membranes. J. Membr. Sci. 1993, 82, 229-236. [CrossRef]

274. Goering, R.M.; Bowman, C.N.; Koval, C.A.; Noble, R.D.; Williamson, D.L. Role of ion-exchange membrane morphology and sorption properties in facilitated transport di-olefin/mono-olefin separations. J. Membr. Sci. 1998, 144, 133-143. [CrossRef]

275. Yave, W.; Shishatskiy, S.; Abetz, V.; Matson, S.; Litvinova, E.; Khotimskiy, V.; Peinemann, K.V. A novel poly(4-methyl-2-pentyne)/TiO2 hybrid nanocomposite membrane for natural gas conditioning: Butane/methane separation. Macromol. Chem. Phys. 2007, 208, 2412-2418. [CrossRef]

276. Hrabánek, P.; Zikánová, A.; Bernauer, B.; Fíla, V.; Kočiřík, M. A route to MFI zeolite- $\alpha$-alumina composite membranes for separation of light paraffins. Desalination 2008, 224, 76-80. [CrossRef]

277. Jung, S.; Palgunadi, J.; Kim, J.H.; Lee, H.; Ahn, B.S.; Cheong, M.; Kim, H.S. Highly efficient metal-free membranes for the separation of acetylene/olefin mixtures: Pyrrolidinium-based ionic liquids as acetylene transport carriers. J. Membr. Sci. 2010, 354, 63-67. [CrossRef]

278. Ni, H.; Hsu, C.S.; Ma, C.; Shi, Q.; Xu, C. Separation and Characterization of Olefin/Paraffin in Coal Tar and Petroleum Coker Oil. Energy Fuels 2013, 27, 5069-5075. [CrossRef] 
279. Wang, Y.; Hao, W.; Jacquemin, J.; Goodrich, P.; Atilhan, M.; Khraisheh, M.; Rooney, D.; Thompson, J. Enhancing Liquid-Phase Ole fi n-Para ffi $n$ Separations Using Novel Silver-Based Ionic Liquids. J. Chem. Eng. Data 2015, 60, 28-36. [CrossRef]

280. Shokrian, M.; Sadrzadeh, M.; Mohammadi, T. Neural Network Modelling of $\mathrm{C}_{3} \mathrm{H}_{8}$ Separation from $\mathrm{CH}_{4}$ and $\mathrm{H}_{2}$ Using PDMS Membrane; Iran University of Science and Technology: Tehran, Iran. Available online: https://www.academia.edu/15943093/NEURAL_NETWORK_MODELLING_OF_C3H8_ SEPARATION_FROM_CH4_and_H2_USING_PDMS_MEMBRANE (accessed on 7 November 2019).

281. Yang, J.; Hsiue, G. Novel dry poly [(1-trimethylsilyl)-1-propyne]-AgC10 4 complex membranes for olefin/paraffin separations. Science 1996, 120, 69-76.

282. Okamoto, K.; Noborio, K.; Hao, J.; Tanaka, K.; Kita, H. Permeation and separation properties of polyimide membranes to 1,3-butadiene and n-butane. J. Membr. Sci. 1997, 134, 171-179. [CrossRef]

283. Wang, Y.; Thompson, J.; Zhou, J.; Goodrich, P.; Atilhan, M.; Pensado, A.S.; Kirchner, B.; Rooney, D.; Jacquemin, J.; Khraisheh, M. Use of water in aiding olefin/paraffin (liquid + liquid) extraction via complexation with a silver bis(trifluoromethylsulfonyl)imide salt. J. Chem. Thermodyn. 2014, 77, 230-240. [CrossRef]

284. Bessarabov, D.G.; Theron, J.P.; Sanderson, R.D.; Schwarz, H.H.; Schossig-Tiedemann, M.; Paul, D. Separation of 1-hexene/n-hexane mixtures using a hybrid membrane/extraction system. Sep. Purif. Technol. 1999, 16, 167-174. [CrossRef]

285. Hsiue, G.; Yang, J. Ag+ contained complex membrane for the separation of C4 olefin/paraffin mixture. J. Polym. Res. 1994, 1, 35-41. [CrossRef]

286. Shen, J.; Zheng, X.; Ruan, H.; Wu, L.; Qiu, J.; Gao, C. Synthesis of AgCl/PMMA hybrid membranes and their sorption performance of cyclohexane/cyclohexene. J. Membr. Sci. 2007, 304, 118-124. [CrossRef]

287. Sungpet, A.; Way, J.D.; Koval, C.A.; Eberhart, M.E. Silver doped Nafion-poly(pyrrole) membranes for facilitated permeation of liquid-phase olefins. J. Membr. Sci. 2001, 189, 271-279. [CrossRef]

288. Rege, S.U.; Padin, J.; Yang, R.T. Olefin/Paraffin Separations by Adsorption: $\pi$-Complexation vs. Kinetic Separation. AIChE J. 1998, 44, 799-809. [CrossRef]

289. Hou, Y.; Li, Y.; Jiang, C.; Xu, Y.; Wang, M.; Niu, Q.J. Molecular simulation for separation of ethylene and ethane by functionalised graphene membrane. Mol. Simul. 2019, 45, 1322-1331. [CrossRef]

290. Chan, S.S.; Wang, R.; Chung, T.-S.; Liu, Y. C2 and C3 hydrocarbon separations in poly(1,5-naphthalene2,2'-bis(3,4-phthalic) hexafluoropropane) diimide (6FDA-1,5-NDA) dense membranes. J. Membr. Sci. 2002, 210, 55-64. [CrossRef]

291. Ilinich, O.M.; Zamaraev, K.I. Separation of ethylene and ethane over polyphenyleneoxides membranes: transient increase of selectivity. J. Membr. Sci. 1993, 82, 141-147. [CrossRef]

292. Staudt-Bickel, C.; Koros, W.J. Olefin/paraffin gas separations with 6FDA-based polyimide membranes. J. Membr. Sci. 2000, 170, 205-214. [CrossRef]

293. Chan, S.S.; Chung, T.S.; Liu, Y.; Wang, R. Gas and hydrocarbon (C2and C3) transport properties of co-polyimides synthesized from 6FDA and 1,5-NDA (naphthalene)/Durene diamines. J. Membr. Sci. 2003, 218, 235-245. [CrossRef]

294. Huang, J.-F.; Luo, H.; Liang, C.; Jiang, D.; Dai, S. Advanced Liquid Membranes Based on Novel Ionic Liquids for Selective Separation of Olefin/Paraffin via Olefin-Facilitated Transport. Ind. Eng. Chem. Res. 2008, 47, 881-888. [CrossRef]

295. Luna-Triguero, A.; Vicent-Luna, J.M.; Gómez-Álvarez, P.; Calero, S. Olefin/Paraffin Separation in Open Metal Site Cu-BTC Metal-Organic Framework. J. Phys. Chem. C 2017, 121, 3126-3132. [CrossRef]

296. Yang, J.S.; Hsiue, G.H. Swollen polymeric complex membranes for olefin/paraffin separation. J. Membr. Sci. 1998, 138, 203-211. [CrossRef]

297. Yang, J.S.; Hsiue, G.H. Selective olefin permeation through Ag(I) contained silicone rubber-graft-poly(acrylic acid) membranes. J. Membr. Sci. 1997, 126, 139-149. [CrossRef]

298. Won, J.; Dong, B.K.; Yong, S.K.; Dai, K.C.; Hoon, S.K.; Chan, K.K.; Chang, K.K. An ab initio study of ionic liquid silver complexes as carriers in facilitated olefin transport membranes. J. Membr. Sci. 2005, 260, 37-44. [CrossRef]

299. Kim, S.H.; Kim, D.B.; Choi, D.K.; Lee, H.; Kim, H.S.; Won, J. Isoprene/pentane separation using facilitated transport membranes. J. Membr. Sci. 2004, 233, 113-117. [CrossRef] 
300. Jiang, C.; Hou, Y.; Wang, N.; Li, L.; Lin, L.; Niu, Q.J. Propylene/propane separation by porous graphene membrane: Molecular dynamic simulation and first-principle calculation. J. Taiwan Inst. Chem. Eng. 2017, 78, 477-484. [CrossRef]

301. Kanezashi, M.; Shazwani, W.N.; Yoshioka, T.; Tsuru, T. Separation of propylene/propane binary mixtures by bis(triethoxysilyl) methane (BTESM)-derived silica membranes fabricated at different calcination temperatures. J. Membr. Sci. 2012, 415-416, 478-485. [CrossRef]

302. Park, J.; Kim, K.; Shin, J.W.; Tak, K.; Park, Y.K. Performance Study of multistage membrane and hybrid distillation processes for propylene/propane separation. Can. J. Chem. Eng. 2017, 95, 2390-2397. [CrossRef]

303. Amedi, H.R.; Aghajani, M. Modified zeolitic-midazolate framework 8/poly(ether-block-amide) mixed-matrix membrane for propylene and propane separation. J. Appl. Polym. Sci. 2018. [CrossRef]

304. Liao, K.S.; Lai, J.Y.; Chung, T.S. Metal ion modified PIM-1 and its application for propylene/propane separation. J. Membr. Sci. 2016, 515, 36-44. [CrossRef]

305. Lee, K.R.; Hwang, S.T. Separation of propylene and propane by polyimide hollow-fiber membrane module. J. Membr. Sci. 1992, 73, 37-45. [CrossRef]

306. Tanaka, K.; Taguchi, A.; Hao, J.; Kita, H.; Okamoto, K. Permeation and separation properties of polyimide membranes to olefins and paraffins. J. Membr. Sci. 1996, 121, 197-207. [CrossRef]

307. Sridhar, S.; Khan, A.A. Simulation studies for the separation of propylene and propane by ethylcellulose membrane. J. Membr. Sci. 1999, 159, 209-219. [CrossRef]

308. Krol, J.J.; Boerrigter, M.; Koops, G.H. Polyimide hollow fiber gas separation membranes: Preparation and the suppression of plasticization in propane/propylene environments. J. Membr. Sci. 2001, 184, 275-286. [CrossRef]

309. Yoshino, M.; Nakamura, S.; Kita, H.; Okamoto, K.I.; Tanihara, N.; Kusuki, Y. Olefin/paraffin separation performance of asymmetric hollow fiber membrane of 6FDA/BPDA-DDBT copolyimide. J. Membr. Sci. 2003, 212, 13-27. [CrossRef]

310. Semenova, S.I. Polymer membranes for hydrocarbon separation and removal. J. Membr. Sci. 2004, 231, 189-207. [CrossRef]

311. Chng, M.L.; Xiao, Y.; Chung, T.S.; Toriida, M.; Tamai, S. Enhanced propylene/propane separation by carbonaceous membrane derived from poly (aryl ether ketone)/2,6-bis(4-azidobenzylidene)-4-methylcyclohexanone interpenetrating network. Carbon 2009, 47, 1857-1866. [CrossRef]

312. Das, M.; Koros, W.J. Performance of 6FDA-6FpDA polyimide for propylene/propane separations. J. Membr. Sci. 2010, 365, 399-408. [CrossRef]

313. Zhang, C.; Dai, Y.; Johnson, J.R.; Karvan, O.; Koros, W.J. High performance ZIF-8/6FDA-DAM mixed matrix membrane for propylene/propane separations. J. Membr. Sci. 2012, 389, 34-42. [CrossRef]

314. Askari, M.; Xiao, Y.; Li, P.; Chung, T.S. Natural gas purification and olefin/paraffin separation using cross-linkable 6FDA-Durene/DABA co-polyimides grafted with $\alpha, \beta$, and $\gamma$-cyclodextrin. J. Membr. Sci. 2012, 390-391, 141-151. [CrossRef]

315. Yang, D.; Le, L.; Martinez, R.; Morrison, M. Hollow fibers structured packings in olefin/paraffin distillation: Apparatus scale-up and long-term stability. Ind. Eng. Chem. Res. 2013, 52, 9165-9179. [CrossRef]

316. Swaidan, R.J.; Ma, X.; Litwiller, E.; Pinnau, I. Enhanced propylene/propane separation by thermal annealing of an intrinsically microporous hydroxyl-functionalized polyimide membrane. J. Membr. Sci. 2015, 495, 235-241. [CrossRef]

317. Najari, S.; Hosseini, S.S.; Omidkhah, M.; Tan, N.R. Phenomenological modeling and analysis of gas transport in polyimide membranes for propylene/propane separation. RSC Adv. 2015, 5, 47199-47215. [CrossRef]

318. Sun, H.-X.; Yuan, B.-B.; Li, P.; Wang, T.; Xu, Y.-Y. Preparation of nanoporous graphene and the application of its nanocomposite membrane in propylene/propane separation. Funct. Mater. Lett. 2015, 08, 1550019. [CrossRef]

319. Visser, T.; Wessling, M. Auto and mutual plasticization in single and mixed gas C3transport through Matrimid-based hollow fiber membranes. J. Membr. Sci. 2008, 312, 84-96. [CrossRef]

320. Giannakopoulos, I.G.; Nikolakis, V. Separation of Propylene/Propane Mixtures Using Faujasite-Type Zeolite Membranes. Ind. Eng. Chem. Res. 2005, 44, 226-230. [CrossRef]

321. Ruthven, D.M.; Reyes, S.C. Adsorptive separation of light olefins from paraffins. Microporous Mesoporous Mater. 2007, 104, 59-66. [CrossRef] 
322. Gascon, J.; Blom, W.; van Miltenburg, A.; Ferreira, A.; Berger, R.; Kapteijn, F. Accelerated synthesis of all-silica DD3R and its performance in the separation of propylene/propane mixtures. Microporous Mesoporous Mater. 2008, 115, 585-593. [CrossRef]

323. Pan, Y.; Li, T.; Lestari, G.; Lai, Z. Effective separation of propylene/propane binary mixtures by ZIF-8 membranes. J. Membr. Sci. 2012, 390-391, 93-98. [CrossRef]

324. Kwon, H.T.; Jeong, H.-K. In Situ Synthesis of Thin Zeolitic-Imidazolate Framework ZIF-8 Membranes Exhibiting Exceptionally High Propylene/Propane Separation. J. Am. Chem. Soc. 2013, 135, 10763-10768. [CrossRef] [PubMed]

325. Eum, K.; Ma, C.; Rownaghi, A.; Jones, C.W.; Nair, S. ZIF-8 Membranes via Interfacial Microfluidic Processing in Polymeric Hollow Fibers: Efficient Propylene Separation at Elevated Pressures. ACS Appl. Mater. Interfaces 2016, 8, 25337-25342. [CrossRef]

326. Yu, J.; Wang, C.; Xiang, L.; Xu, Y.; Pan, Y. Enhanced C3H6/C3H8 separation performance in poly(vinyl acetate) membrane blended with ZIF-8 nanocrystals. Chem. Eng. Sci. 2018, 179, 1-12. [CrossRef]

327. Shrestha, S.; Dutta, P.K. Modification of a continuous zeolite membrane grown within porous polyethersulfone with $\mathrm{Ag}(\mathrm{I})$ cations for enhanced propylene/propane gas separation. Microporous Mesoporous Mater. 2019, 279, 178-185. [CrossRef]

328. Maghsoudi, H. Theoretical screening zeolites for membrane separation of propylene/propane mixtures. Polyolefins J. 2017, 5, 1-14.

(C) 2019 by the authors. Licensee MDPI, Basel, Switzerland. This article is an open access article distributed under the terms and conditions of the Creative Commons Attribution (CC BY) license (http://creativecommons.org/licenses/by/4.0/). 